\title{
Denitrification of groundwater with pyrite and
}

\section{Thiobacillus denitrificans}

Clara Torrentó ${ }^{(1, *)}, J_{0 r d i}$ Cama ${ }^{(1)}$, Jordi Urmeneta ${ }^{(2)}$, Neus Otero ${ }^{(3)}$ and Albert Soler ${ }^{(3)}$.

(1) Hydrogeochemistry Group, Institute of Environmental Assessment and Water Research IDAEA, CSIC, C/Jordi Girona, 18-26, 08034 Barcelona, Spain. clara.torrento@idaea.csic.es, jordi.cama@idaea.csic.es

(2) Department of Microbiology and Biodiversity Research Institute (IRBio), University of Barcelona, Av. Diagonal 645, 08028 Barcelona, Spain. jurmeneta@ub.edu

(3) Mineralogia Aplicada i Medi Ambient Group, Department of Crystallography, Mineralogy and Ore Deposits, University of Barcelona, Martí i Franquès s/n, 08028 Barcelona, Spain. notero@ub.edu, albertsolergil@ub.edu

(*) Corresponding author: Clara Torrentó e-mail: clara.torrento@idaea.csic.es Fax: +34 934110012. 


\section{Abstract}

3 Anaerobic batch and flow-through experiments were performed to confirm the role of pyrite as

4 electron donor in bacterial denitrification and to look into the feasibility of pyrite-driven

5 denitrification of nitrate-contaminated groundwater. Nitrate reduction was satisfactorily

6 accomplished in experiments with pyrite as the sole electron donor, in presence of the autotrophic

7 denitrifying bacterium Thiobacillus denitrificans and at nitrate concentrations comparable to those

8 observed in contaminated groundwater. The experimental results corroborated field studies in which

9 the reaction occurred in aquifers. Nitrate reduction rates and nitrate removal efficiencies were

10 dependent on pyrite grain size, initial nitrate concentration, nitrate-loading rate and $\mathrm{pH}$. The $\mathrm{N}$ and $\mathrm{O}$

11 isotopic enrichment factors $(\varepsilon \mathrm{N}$ and $\varepsilon \mathrm{O})$ obtained experimentally for pyrite-driven nitrate reduction

12 by Thiobacillus denitrificans ranged from $-13.5 \%$ to $-15.0 \%$ o and from $-19.0 \%$ o to $-22.9 \%$, respectively.

13 These values indicated the magnitude of the isotope fractionation that occurs in nitrate-contaminated 14 aquifers dominated by autotrophic denitrification.

15 Keywords: denitrification, pyrite, dissolution, Thiobacillus denitrificans, isotope fractionation. 


\section{INTRODUCTION}

17 Groundwater contamination by nitrate usually originates from anthropogenic sources, mainly as a

18 result of wastewater discharges and the intensive application of fertilizers and animal manure to agricultural land. It is not unusual for groundwater nitrate concentration to exceed the nominal limit of $50 \mathrm{mg} \mathrm{L}^{-1}$ set by the 98/83/EC European Union Council Directive.

Water remediation is necessary to prevent public-health and environmental impacts. The most significant natural attenuation process is denitrification, i.e. the reduction of nitrate to dinitrogen gas by anaerobic facultative bacteria (and a few archaea) that utilize nitrate as the electron acceptor (Knowles, 1982; Zumft, 1997). Bacteria that are capable of denitrification are ubiquitous with the result that denitrification occurs throughout terrestrial, freshwater, and marine systems where the following conditions arise simultaneously: (i) nitrate and electron donor availability, (ii) low oxygen concentrations (dissolved oxygen concentrations less than around 1-2 mg L-1, Cey et al., 1999; Korom, 1992), and (iii) favorable environment (temperature, $\mathrm{pH}$, other nutrients and trace elements). Denitrifying bacteria are generally heterotrophic and utilize organic matter as the electron donor. Nevertheless, a limited number of bacteria are capable of carrying out chemolithotrophic denitrification and of using inorganic compounds such as reduced sulfur compounds, hydrogen, ferrous iron or uranium (IV) as electron donors, and inorganic carbon $\left(\mathrm{CO}_{2}\right.$ or $\left.\mathrm{HCO}_{3}\right)$ as the carbon source for cell material synthesis (Beller, 2005; Straub et al., 1996; Zumft, 1997). The obligate chemolithoautotrophic bacterium Thiobacillus denitrificans is well known for its ability to couple the oxidation of various sulfur and reduced iron compounds to denitrification (Beller et al., 2006). 
A number of field studies have demonstrated the occurrence of natural denitrification coupled to oxidation of pyrite based on geochemical and/or isotopic data (Aravena and Robertson, 1998; Beller et al., 2004; Cravotta, 1998; Le Bideau and Dudoignon, 1996; Otero et al., 2009; Pauwels et al., 1998, 2000, 2010; Postma et al., 1991; Schwientek et al., 2008; Zhang et al., 2009). Denitrification by pyrite oxidation is expressed as:

$$
14 \mathrm{NO}_{3}^{-}+5 \mathrm{FeS}_{2}+4 \mathrm{H}^{+} \Rightarrow 7 \mathrm{~N}_{2}+10 \mathrm{SO}_{4}^{2-}+5 \mathrm{Fe}^{2+}+2 \mathrm{H}_{2} \mathrm{O}
$$

If the $\mathrm{Fe}^{2+}$ produced is oxidized:

$$
\mathrm{NO}_{3}^{-}+5 \mathrm{Fe}^{2+}+6 \mathrm{H}^{+} \Rightarrow \frac{1}{2} \mathrm{~N}_{2}+5 \mathrm{Fe}^{3+}+3 \mathrm{H}_{2} \mathrm{O}
$$

$$
15 \mathrm{NO}_{3}^{-}+5 \mathrm{FeS}_{2}+10 \mathrm{H}_{2} \mathrm{O} \Rightarrow \frac{15}{2} \mathrm{~N}_{2}+10 \mathrm{SO}_{4}^{2-}+5 \mathrm{Fe}(\mathrm{OH})_{3}+5 \mathrm{H}^{+}
$$

Our interest is to characterize this pyrite-driven denitrification reaction and assess its feasibility. Although much work has been devoted to enhancing autotrophic denitrification by adding several inorganic electron donors, such as zero-valent iron, ferrous ions, elemental sulfur, and iron bearing materials (Benz et al., 1998; Choe et al., 2004; Hansen et al., 2001; Postma, 1990; Sierra-Alvarez et al., 2007; Soares, 2002; Straub et al., 1996; Weber et al., 2001), fewer studies have been carried out on nitrate reduction by pyrite and other sulfide minerals (Devlin et al., 2000; Haaijer et al., 2007; Jorgensen et al., 2009; Schippers and Jorgensen, 2002). In these studies, the role of pyrite as electron donor has been questioned and only in Jorgensen et al. (2009), has been denitrification coupled to 54 pyrite oxidation satisfactorily accomplished. These authors performed pyrite-amended batch 55 experiments with sediment from a sandy aquifer and demonstrated that addition of pyrite increased nitrate reduction rates. However, little is still known about the kinetics, the limiting factors and the 
57 involvement of T. denitrificans-like bacteria in this reaction. Therefore, the first goal of this paper is to

58 determine, clarify and quantify the role of pyrite as an electron donor in the bacterial mediated 59 denitrification process in order to assess its feasibility for nitrate remediation in contaminated 60 groundwater.

61 In addition, $\mathrm{N}$ and $\mathrm{O}$ isotope fractionation has been qualitatively used to study natural bacterially 62 mediated nitrate reduction in contaminated aquifers (Otero et al., 2009). However, to quantify field 63 denitrification, the enrichment factor $(\varepsilon)$ must be determined with reasonable accuracy. $\mathrm{N}$ and $\mathrm{O}$ 64 enrichment factors have been determined in groundwater field studies (Böttcher et al., 1990; Fukada et 65 al., 2003; Mengis et al., 1999) and in laboratory pure culture experiments with denitrifying cultures 66 (Barford et al., 1999; Delwiche and Steyn, 1970; Wellman et al., 1968). The latter studies are extremely 67 useful because they provide a basis for the interpretation of field data, highlighting the magnitude of 68 fractionation that could occur in different groups of microorganisms under specific biogeochemical 69 conditions. These estimations have been performed with pure cultures of heterotrophic denitrifying bacteria. To our knowledge, isotope fractionation during autotrophic denitrification in laboratory 71 cultures has not been reported to date. Therefore, the second goal of this study is to characterize 72 nitrogen and oxygen isotope fractionation for pyrite-driven denitrification by $T$. denitrificans in order 73 to evaluate the magnitude of the isotopic fractionation expected in nitrate-contaminated aquifers.

74 To accomplish both goals, two types of experiments with powdered pyrite were performed: (1) 75 batch experiments inoculated with pure culture of $T$. denitrificans to study the overall reaction and 76 determine isotope fractionation and (2) long-term flow-through experiments to evaluate the 77 performance of the denitrification process over time and under flow conditions. 


\section{MATERIALS AND METHODS}

\subsection{Pyrite characterization and preparation}

80

81

82

83

84

85

86

87

88

89

90

91

92

93

94

95

96

97

98

Natural pyrite crystals were obtained from sedimentary deposits in Navajún (Logroño, Spain) and from metasedimentary deposits in the Cerdanya region (Catalan Pyrenees, Spain). Powder X-ray diffraction of the samples was determined using a Bruker D5005 difractometer with $\mathrm{Cu} \mathrm{K} \alpha$ radiation over a $2 \theta$ range from 0 to 60 degrees with a scan speed of $0.025^{\circ} / 18 \mathrm{~s}$. The X-ray patterns confirmed the samples to be pyrite and showed no evidence of the presence of any other mineral phase. Based on electron microprobe analysis (EMPA), the Navajún pyrite atomic composition was 66.5 at.\% of S and 33.3 at.\% of Fe with impurities of $\mathrm{Ni}(0.07 \pm 0.05$ at.\%). The atomic composition of the Cerdanya pyrite was 66.5 at \% of S and 33.3 at.\% of Fe with impurities of $\mathrm{Ni}, \mathrm{Co}$ and $\mathrm{Cu}(0.06 \pm 0.04,0.04 \pm 0.06$ and $0.04 \pm 0.03$ at. $\%$, respectively).

Pyrite samples were crushed and sieved to obtain two particle sizes, one ranging from 25 to $50 \mu \mathrm{m}$ and the other from 50 to $100 \mu \mathrm{m}$. The samples used in two blank (TD-blank-21 and TD-blank-22, Table 1) and in two pyrite-amended (TD-13 and TD-14, Table 2) batch experiments were washed with $6 \mathrm{M} \mathrm{HCl}$ solution for $5 \mathrm{~min}$ and then rinsed with Milli-Q pure water three times before the start of the experiments to remove microparticles and possible iron and sulfur impurities on the pyrite surface. Specific surface areas were determined by the BET gas adsorption method with a Micromeritics ASAP 2000 surface area analyzer using 5-point $\mathrm{N}_{2}$ adsorption isotherms (Brunauer et al., 1938). Initial surface areas for $25-50 \mu \mathrm{m}$ particles were $0.59 \pm 0.06 \mathrm{~m}^{2} \mathrm{~g}^{-1}$ for the Navajún pyrite and $0.88 \pm 0.09 \mathrm{~m}^{2} \mathrm{~g}^{-1}$ for the Cerdanya pyrite (from here on all values are mean \pm standard deviation unless otherwise noted). Surface areas for 50-100 $\mu \mathrm{m}$ particles were $0.43 \pm 0.04 \mathrm{~m}^{2} \mathrm{~g}^{-1}$ and $0.62 \pm 0.06 \mathrm{~m}^{2} \mathrm{~g}^{-1}$, respectively. After the 
experiments, BET specific surface area of reacted samples was also measured. Pyrite powders for use

100 in batch and inoculated flow-through experiments were sterilized by autoclave at $121^{\circ} \mathrm{C}$ for $15 \mathrm{~min}$.

101 X-ray Photoelectron spectra (XPS) of initial and reacted samples were recorded with a Physical

102 Electronics (PHI) 5500 spectrometer using a monochromatic X-ray source with an Al Ka line of 1486.6

$103 \mathrm{eV}$ energy and operated at $350 \mathrm{~W}$. The energy scale was calibrated using the $3 \mathrm{~d}_{5 / 2}$ line for Ag with a

104 width of $0.8 \mathrm{eV}$ and a binding energy of $368.3 \mathrm{eV}$. All binding energies were corrected by adjusting the

105 C1s peak (corresponding to contamination from hydrocarbons) to a binding energy of $284.6 \mathrm{eV}$.

106 Atomic concentrations of iron and sulfur were determined from the XPS areas subsequent to the 107 Shirley background subtraction divided by atomic sensitivity factors (Wagner, 1983).

\subsection{Culture preparation}

109

Thiobacillus denitrificans (strain DSMZ No. 12475 from German Collection of Microorganisms and

110 Cell Cultures, Germany) was cultured with thiosulfate in an anaerobic ( $\mathrm{pH}$ 6.8) nutrient medium

111 specially designed for $T$. denitrificans, following Beller (2005). The medium consisted of a mixed

112 solution of $\mathrm{Na}_{2} \mathrm{~S}_{2} \mathrm{O}_{3} \cdot 5 \mathrm{H}_{2} \mathrm{O}(20 \mathrm{mM}), \mathrm{NH}_{4} \mathrm{Cl}(18.7 \mathrm{mM}), \mathrm{KNO}_{3}(20 \mathrm{mM}), \mathrm{KH}_{2} \mathrm{PO}_{4}(14.7 \mathrm{mM}), \mathrm{NaHCO}_{3}$

$113(30 \mathrm{mM}), \mathrm{MgSO}_{4} \cdot 7 \mathrm{H}_{2} \mathrm{O}(3.25 \mathrm{mM}), \mathrm{FeSO}_{4} \cdot 7 \mathrm{H} 2 \mathrm{O}(0.08 \mathrm{mM}), \mathrm{CaCl}_{2} \cdot 2 \mathrm{H}_{2} \mathrm{O}(0.05 \mathrm{mM})$ and sterile vitamin,

114 trace element and selenate-tungstate solutions (stock solutions 1, 4, 6, 7 and 8 of Widdel and Bak,

115 1992). Cultures were maintained under anaerobic conditions at $30^{\circ} \mathrm{C}$ and unshaken. Thereafter, the

116 culture was harvested by centrifugation, washed, and resuspended in sterile saline solution (Ringer

$117 \quad 1 / 4$ solution) immediately before the start of the experiments.

\subsection{Experimental set-up}



pressure in the glove box was maintained between 0.1 and $0.3 \% \mathrm{O}_{2}(\mathrm{~g})$, being continuously monitored

122 by an oxygen partial pressure detector with an accuracy of $\pm 0.1 \% \mathrm{O}_{2}(\mathrm{~g})$. Input solutions were 123 introduced into the glove box at least $12 \mathrm{~h}$ before the start of the experiments to allow equilibration 124 with the anaerobic atmosphere and were sparged with $\mathrm{N}_{2}$ for $15 \mathrm{~min}$ before the start of the 125 experiments. The solutions to be autoclaved were degassed before the sterilization. All the 126 experiments were set up with nitrate as the electron acceptor and pyrite as the sole electron donor.

127 Pyrite was added in stoichiometric excess with respect to added nitrate.

128 Three types of batch experiments were performed: control experiments (Table 1), T. denitrificans129 inoculated experiments amended with pyrite (Table 2), and experiments designed to calculate isotope 130 fractionation (Table 3).

131 Two groups of independent control experiments were performed (Table 1): (1) pyrite-free 132 experiments (both inoculated and non-inoculated) and (2) sterilized blank experiments with pyrite.

133 Pyrite-amended batch experiments were performed to confirm the occurrence of pyrite-driven 134 nitrate reduction and to evaluate the nitrate removal rate by T. denitrificans (Table 2). Two groups of 135 experiments were conducted with two different sizes of Navajún pyrite particles (25-50 and 50-100 $136 \mu \mathrm{m}$ ). Each group included three different initial cell densities (approx. $10^{5}, 10^{7}$ or $10^{8}$ cells $\mathrm{mL}^{-1}$ ). For 137 each cell density, three different initial nitrate concentrations (approx. 1, 2.5 or $4 \mathrm{mM}$ ) were used. Each 138 experiment performed with approximately $10^{8}$ cells $\mathrm{mL}^{-1}$ was repeated 3-4 times in order to assess the 139 reproducibility of the results (Table 2). $50 \mathrm{~mL}$ polypropylene bottles were filled with $25 \mathrm{~mL}$ of $\mathrm{pH}$ 6.81407.0 modified medium with the desired concentration of nitrate, and $5 \mathrm{~g}$ of sterilized pyrite powder 
141 with the desired grain size were added. The modified medium used in the batch experiments was the

142 T. denitrificans nutrient medium without thiosulfate and iron, replacing sulfate salts by chloride salts

143 and adding the desired nitrate concentration: $\mathrm{NH}_{4} \mathrm{Cl}(18.7 \mathrm{mM}), \mathrm{KH}_{2} \mathrm{PO}_{4}(14.7 \mathrm{mM}), \mathrm{NaHCO}_{3}(30$

$144 \mathrm{mM}), \mathrm{MgCl}_{2} \cdot 6 \mathrm{H}_{2} \mathrm{O}(3.25 \mathrm{mM})$ and $\mathrm{CaCl}_{2} \cdot 2 \mathrm{H}_{2} \mathrm{O}(0.05 \mathrm{mM})$ and the desired $\mathrm{NO}_{3}{ }^{-}$concentration as $\mathrm{KNO}_{3}$.

145 Under these conditions pyrite will be the only electron donor available for the cells. Preliminary

146 experiments showed that initial pyrite-solution interaction caused a decrease in $\mathrm{pH}$ to below 6 . This

147 was likely due to dissolution of surface grinding-resulted microparticles and possible surficial S-

148 impurities. This $\mathrm{pH}$ drop considerably diminished bacterial activity. Denitrification efficiency is very

149 sensitive to $\mathrm{pH}$ and an optimum $\mathrm{pH}$ range for most denitrifying bacteria is 7-8 (Knowles, 1982).

150 Therefore, after 24-42 h, the supernatant was eliminated and replaced by the fresh input solution.

151 After $48 \mathrm{~h}$, aqueous samples corresponding to time 0 were collected and flasks were inoculated with 1

$152 \mathrm{~mL}$ of cell solution with the desired cell density. To ensure that the possible presence of microparticles

153 and/or oxidation products on the pyrite surface has no significant effect on the rate and efficiency of

154 the reaction, two pyrite-amended experiments were performed with HCl-washed pyrite (TD-13 and

155 TD-14, Table 2).

156 In the experiments designed to characterize nitrogen and oxygen isotope fractionation associated

157 with the process (Table 3), the procedure was the same but using $250 \mathrm{~mL}$ glass Witeg bottles with 100

$158 \mathrm{~mL}$ of solution and $20 \mathrm{~g}$ of pyrite; $4 \mathrm{~mL}$ of culture were inoculated into each flask.

159 Batch experiments were run for $14 \mathrm{~d}(25-50 \mu \mathrm{m}$ pyrite) or for $60 \mathrm{~d}$ (50-100 $\mu \mathrm{m}$ pyrite and pyrite-free

160 experiments) and aqueous samples were periodically taken using sterile syringes. The number of

161 samples was limited to maintain the solid-solution ratio at $<30 \%$ of the initial value. 
163 similar conditions to the natural environment and to evaluate the long-term performance of the 164 process. Three types of flow-through experiments were performed: inoculated, blank and non165 inoculated (Table 4). By means of a peristaltic pump, input solutions were circulated through $50 \mathrm{~mL}$ 166 polyethylene reactors in which $50-100 \mu \mathrm{m}$ powdered Cerdanya pyrite (approximately $1 \mathrm{~g}$ in the blank 167 and non-inoculated experiments and $10 \mathrm{~g}$ in the inoculated experiment) was placed.

168 The T. denitrificans-inoculated experiment was carried out to evaluate the response and the 169 denitrification capability of the pure culture over long term (several months). After $15 \mathrm{~d}$ of inoculation $170\left(6.6 \times 10^{7}\right.$ cells $\left.\mathrm{mL}^{-1}\right)$, solution was circulated through the reactor with a flow rate of $0.003 \mathrm{~mL} \mathrm{~min}^{-1}$, 171 yielding a hydraulic retention time (HRT) of $11.6 \mathrm{~d}$. Reactors, tubing, pyrite powder and solutions 172 were sterilized before use in the inoculated experiment and also in the blank experiment.

173 The non-inoculated experiments, with non-sterilized pyrite powder, were performed to stimulate 174 activity of indigenous bacteria. The flow rate ranged between 0.009 and $0.014 \mathrm{~mL} \mathrm{~min}^{-1}$, yielding HRT 175 of 2.3-3.9 d. These non-inoculated experiments were replicated to ensure the reproducibility of the 176 results (Table 4).

177 Input solution in the inoculated experiment was the modified T. denitrificans medium solution with $1782.5 \mathrm{mM} \mathrm{KNO}_{3}$ (nitrate loading rate of $0.21 \mathrm{mmol} \mathrm{NO}^{-} \mathrm{L}^{-1} \mathrm{~d}^{-1}$ ). Input solutions in the blank and non179 inoculated experiments consisted of $\mathrm{NaNO}_{3}$ solutions with nitrate concentration between 0.4 and 2.5 180 $\mathrm{mM}$, yielding nitrate loading rates from 0.11 to $0.50 \mathrm{mmol} \mathrm{NO}^{-} \mathrm{L}^{-1} \mathrm{~d}^{-1}$. In the two solutions, no other 181 electron donor was added to ensure that pyrite was the only electron donor available for cells. In 182 order to ensure an optimal $\mathrm{pH}, \mathrm{pH}$ of influent solutions was between 6.5 and 8 . Nevertheless, one of 
183 the non-inoculated experiments (NON-1, Table 4) was carried out at $\mathrm{pH} 4.5$ to confirm the fatal effect 184 of $\mathrm{pH}$ on nitrate reduction.

185 Experimental runs lasted between 200 and $375 \mathrm{~d}$ and output solutions were collected periodically.

\subsection{Analytical methods}

187

Aliquots of aqueous samples were filtered through $0.22 \mu \mathrm{m}$ syringe filters to measure $\mathrm{pH}$, concentrations of cations, anions, ammonium, and, in some samples, $\delta^{15} \mathrm{~N}$ and $\delta^{18} \mathrm{O}$ of dissolved

nitrate. Samples were preserved in nitric acid to measure concentrations of total $\mathrm{Fe}$, total S, Mg, $\mathrm{Ca}$,

$\mathrm{Na}, \mathrm{Cl}, \mathrm{P}$, and $\mathrm{K}$ by inductive coupled plasma-atomic emission spectrometry (ICP-AES, Thermo Jarrel-

Ash with CID detector and a Perkin Elmer Optima 3200 RL). The accuracy on the measurement of Mg,

$\mathrm{Ca}, \mathrm{Na}, \mathrm{Cl}, \mathrm{P}$ and $\mathrm{K}$ was estimated to be around $3 \%$, whereas the accuracy on the measurement of $\mathrm{Fe}$ 193 and S was estimated to be $25 \%$, with detection limits of 0.36 and $3.12 \mu \mathrm{mol} \mathrm{L}^{-1}$, respectively. Anion concentrations (nitrate, nitrite, chloride, and sulfate) were determined by High Performance Liquid

Chromatography (HPLC), using an IC-Pack Anion column and borate/gluconate eluent with $12 \%$ of HPLC grade acetonitrile. The error associated with the measurements was estimated to be $5 \%$ for nitrate, chloride and sulfate and $10 \%$ for nitrite. Samples for ammonium analysis were preserved acidified to $\mathrm{pH}<2$ with $\mathrm{H}_{2} \mathrm{SO}_{4}$. Ammonium concentrations were measured using an Orion ammonium ion selective electrode with an analytical uncertainty of $10 \%$ and a detection limit of $0.01 \mathrm{mM}$. $\mathrm{pH}$ was measured with a calibrated Crison $\mathrm{pH}$ Meter at room temperature $\left(22 \pm 2{ }^{\circ} \mathrm{C}\right)$. The $\mathrm{pH}$ error was 0.02 201 pH units.

202 Samples for $\mathrm{N}$ and $\mathrm{O}$ isotopes of nitrate were stored in $\mathrm{KOH}(\mathrm{pH} 11)$ solution and frozen prior to analysis. The $\delta^{15} \mathrm{~N}$ and $\delta^{18} \mathrm{O}$ of dissolved nitrate were obtained following the denitrifier method 
204 (Casciotti et al., 2002; Sigman et al., 2001). Notation is expressed in terms of $\delta$ per mil relative to the 205 international standards: V-SMOW (Vienna Standard Mean Oceanic Water) for $\delta^{18} \mathrm{O}$ and AIR 206 (Atmospheric $\mathrm{N}_{2}$ ) for $\delta^{15} \mathrm{~N}$. The isotope ratios were calculated using international and internal 207 laboratory standards. The results had an accuracy of $0.2 \%$ for $\delta^{15} \mathrm{~N}$ and $0.5 \%$ or for $\delta^{18} \mathrm{O}$ of nitrate.

\section{RESULTS AND DISCUSSION}

\subsection{Nitrate reduction}

In the control batch experiments, nitrate concentrations remained unchanged up to $60 \mathrm{~d}$ (Table 1).

211 Consumption of nitrate over time was only observed in the pyrite-amended, T. denitrificans-inoculated 212 batch experiments (Fig. 1). The time needed to consume nitrate was dependent on pyrite grain size 213 and initial nitrate concentration. In most of the experiments with 25-50 $\mu \mathrm{m}$ pyrite, nitrate content was 214 mostly consumed within $14 \mathrm{~d}$ (Fig. 1A). In cultures amended with 50-100 $\mu$ m pyrite, the time needed 215 to consume most nitrate was longer and decreased by lowering the initial nitrate concentration. With 216 an initial concentration of approx. $4 \mathrm{mM} \mathrm{NO}^{-}, 35$ to $80 \%$ of the nitrate content was consumed after 60 $217 \mathrm{~d}$; with approx. $2.5 \mathrm{mM} \mathrm{NO}{ }^{-}$, nitrate was completely consumed within $60 \mathrm{~d}$; and with approx. $1 \mathrm{mM}$ 218 of $\mathrm{NO}_{3}$, complete consumption of nitrate occurred within $14 \mathrm{~d}$ (Fig. 1B).

219 An initial stage of $7 \mathrm{~d}$ during which nitrate concentration barely decreased was observed with the 220 lowest initial cell density $\left(\sim 10^{5}\right.$ cells $\left.\mathrm{mL}^{-1}\right)$ (data not shown). This occurred because a longer adaptation 221 time was necessary for bacteria to grow into a population large enough to bring about a detectable 222 change in nitrate concentration. Nevertheless, the final percentages of reduced nitrate tended to 223 resemble those of experiments with higher initial cell density (Table 2). 
As regards the flow-through experiments, nitrate reduction occurred in all the non-inoculated and 226 inoculated experiments, but not in the blank experiment. In the T. denitrificans-inoculated experiment, 227 partial nitrate removal occurred for 70 d (Fig. 2A). Subsequently, complete nitrate removal was 228 achieved and lasted until the end of the experiment (200 d), indicating a high long-term efficiency of 229 T. denitrificans in nitrate removal using pyrite as the electron donor under the study conditions. Figure 2B shows the consumption of nitrate in one representative non-inoculated flow-through experiment. 231 In these experiments, a maximum nitrate reduction was achieved after 50-200 d (Table 4). Thereafter, nitrate content remained fairly constant until nitrate reduction slowed down to stop (e.g. NON-3a, Fig. 2B). Nonetheless, in some experiments after an apparent cessation of nitrate reduction, reduction restarted and high nitrate removal efficiency (expressed as the percentage of maximum nitrate removal) (60-94\%) was finally attained (e.g. NON-2, Fig. 3A). In three experiments, a lag of approximately 80-100 d was observed before nitrate reduction started (e.g. NON-4a, Fig. 3B). In other experiments, nitrate reduction apparently did not cease during the duration of the tests (e.g. NON-4c, Fig. 3C). These behaviors could be attributed to shifts over the course of the runs in the composition of the dominant microbial community or in the enzyme regulation of the denitrifying organisms, probably as a result of changes in the experimental conditions that control the activity and growth of bacteria (such as oxygen concentration or nutrient availability). At $\mathrm{pH} 4.5$ (NON-1), nitrate reduction was less effective than that observed in experiments carried out at $\mathrm{pH} 6.5-8$, confirming the marked decrease in microbial activity due to acid $\mathrm{pH}$ (Table 4). Nitrate reduction efficiency was dependent on 244 the nitrate loading rate. As is shown in the Table 4, when the nitrate loading rate ranged between 0.11 245 and $0.25 \mathrm{mmol} \mathrm{NO}_{3} \mathrm{~L}^{-1} \mathrm{~d}^{-1}$, nitrate reduction was effective (overall nitrate removal of 40-80\%), lasting 
up to $150-350 \mathrm{~d}$. By contrast, with high nitrate loading rates $\left(0.33-0.50 \mathrm{mmol} \mathrm{NO}_{3}-\mathrm{L}^{-1} \mathrm{~d}^{-1}\right)$, nitrate reduction efficiency was lower (overall nitrate removal lower than $30 \%$ ), lasting only $20-70 \mathrm{~d}$ (e.g. NON-6b, Fig. 3D). It should be noted that, although efficiency in nitrate removal was different, the maximum amount of nitrate removed was similar in the two cases (between 0.12 and $0.48 \mathrm{mM}$ for lower nitrate loading rates and $0.31-0.38 \mathrm{mM}$ for higher ones). Therefore, a maximum nitrate removal of $0.48 \mathrm{mM}$ was attained, regardless of the input concentration of nitrate.

Nitrate reduction to diatomic nitrogen gas occurs in four steps, nitrite being one of the intermediate products. The basic nitrate reduction pathway is represented as $\mathrm{NO}_{3}^{-} \rightarrow \mathrm{NO}_{2}^{-} \rightarrow \mathrm{NO} \rightarrow \mathrm{N}_{2} \mathrm{O} \rightarrow \mathrm{N}_{2}$.

In most of the pyrite-amended batch experiments nitrite reduction took place rapidly and the final products were $\mathrm{N}$-gaseous compounds (i.e. $\mathrm{NO}, \mathrm{N}_{2} \mathrm{O}$ or $\mathrm{N}_{2}$ ). Furthermore, no changes in the ammonium concentration were detected over time, ruling out dissimilatory nitrate reduction to ammonium (Korom, 1992). Beller et al. (2006) showed that T. denitrificans has all the necessary genes encoding the four essential enzymes that catalyze denitrification. Our results confirm that these bacteria are able to reduce, at least, nitrate and nitrite. However, transient nitrite accumulation was evident in 6 batch experiments (TD-1a, TD-1b, TD-1c, TD-2a, TD-2b and TD-2c). Two examples are shown in Figure 1C. Peak nitrite concentrations were observed after $43 \mathrm{~d}$, accounting for $15-35 \%$ of the initial nitrate concentration. Thereafter, nitrite concentration decreased. Nitrite was also present in some output solutions in the flow-through experiments. In the inoculated experiment, nitrite 265 accumulated during the first $70 \mathrm{~d}$, after which a complete nitrate removal was attained (Fig. 2A). In most of the non-inoculated flow-through experiments, nitrate reduction consisted of two stages. In the 
268 nitrite was produced before the denitrification ceased. An example is given in the Figure 4. As 269 occurred in the batch experiments, dissimilatory nitrate reduction to ammonium could be excluded 270 because ammonium concentrations in the output solutions were always below the detection limit.

271 In both the batch and flow-through experiments, nitrite accumulation resulted from the incomplete 272 reduction of nitrate. Since pyrite was the sole electron donor and was placed in excess to avoid 273 electron donor limitation, nitrite accumulation could be due to the competition between nitrate and 274 nitrite reductases for the available electron donor. In this regard, high nitrate content has been found 275 to inhibit nitrite reduction, inducing nitrite accumulation (Betlach and Tiedje, 1981; Blaszczyk, 1993; 276 Thomsen et al., 1994; Van Rijn et al., 1996).

277 In summary, nitrate removal efficiency diminished as a result of an increase in nitrate concentration 278 (i.e. nitrate loading rate) and in pyrite grain size, and as a result of a decrease in $\mathrm{pH}$. A $100 \%$ efficiency 279 in nitrate removal was achieved in the presence of T. denitrificans. Under non-sterilized, non280 inoculated conditions, nitrate removal efficiency was lower, probably because of changes in the 281 microbial population. Nitrite reduction yielded N-gaseous compounds although transient nitrite 282 accumulation occurred in the open-system experiments.

\subsection{Stoichiometry of the pyrite-driven denitrification process}

In both batch and flow-through experiments, pyrite dissolution was confirmed by $\mathrm{S}$ release. The HPLC measurements for sulfate concentrations were concordant within $\pm 5 \%$ with the sulfate concentrations calculated from ICP sulfur elemental data, assuming that concentrations of non-sulfate sulfur species (sulfides and sulfites) were negligible. In the batch experiments, an initial high $S$ release 
occurred simultaneously to the reduction of nitrate in the inoculated experiments. The gradual increase in S concentration was also observed in the blank experiments and it was in general lower than in the inoculated experiments (Fig. 5A). This suggests that part of the $S$ released in the inoculated experiments could be attributed to pyrite oxidation by traces of dissolved oxygen as observed in the blank experiments. Iron concentrations in all the batch experiments were below the detection limit, given that reacting $\mathrm{pH}$ ranged between 6.5 and 7.5. In the flow-through experiments, output $\mathrm{S}$ concentrations were higher at the start of the experiments, subsequently decreasing until a steady state was attained (Fig. 5B). High concentrations at the start of the experiments were probably due to dissolution of an outer layer of the reacting mineral or to dissolution of microparticles (Lasaga, 1998). Iron concentrations were below the detection limit in all the flow-through experiments.

Therefore, the results of both batch and flow-through experiments show that nitrate reduction occurred concurrently with the release of sulfate in the sterilized pyrite-amended experiments inoculated with $T$. denitrificans and in the non-inoculated experiments with non-sterilized pyrite, which showed inherent activity of indigenous bacteria. Under sterile conditions or under the conditions of not adding pyrite, nitrate reduction did not occur. This indicates that nitrate reduction was coupled with pyrite dissolution and was mediated by bacteria. Iron concentration was below detection limit, suggesting that most of the $\mathrm{Fe}^{2+}$ resulting from pyrite oxidation was oxidized to $\mathrm{Fe}^{3+}$ and precipitated. As stated in section 3.1, ammonium production could be excluded. Accordingly, the overall reaction can be expressed as eq.(3).

If nitrate reduction was coupled to pyrite dissolution via eq. (3), the measured molar ratio of nitrate consumed to sulfate produced should be close to the stoichiometric ratio of this reaction, which is 1.5. 
311 nitrate/sulfate ratio was calculated based on the amount of nitrite accumulated according to the 312 following reaction:

$$
15 \mathrm{NO}_{3}^{-}+2 \mathrm{FeS}_{2}+7 \mathrm{H}_{2} \mathrm{O} \Rightarrow 15 \mathrm{NO}_{2}^{-}+4 \mathrm{SO}_{4}^{2-}+2 \mathrm{Fe}(\mathrm{OH})_{3}+8 \mathrm{H}^{+}
$$

314 where nitrate/sulfate ratio is 3.75 .

315 In most of the experiments, the final products of the overall reaction were gaseous N-compounds 316 (i.e. $\mathrm{NO}, \mathrm{N}_{2} \mathrm{O}$ or $\mathrm{N}_{2}$ ). If the product was $\mathrm{NO}$ or $\mathrm{N}_{2} \mathrm{O}$, the nitrate/sulfate ratio should be 2.5 (eq. 5) and 1.9 (eq. 6), respectively:

In the inoculated pyrite-amended batch experiments, the nitrate/sulfate ratio was calculated using sulfate released after time 0 given that nitrate reduction started after this time. The ratio ranged from 3220.4 to 2.0, being lower than the possible stoichiometric ratios in most experiments (Table 2). 323 Nevertheless, the ratio was 1.5 within a 15\% error in seven experiments. The low nitrate/sulfate ratio 324 indicates excess of sulfate, which, as stated above, could be explained by additional oxidation of pyrite 325 by traces of dissolved oxygen as observed in the blank experiments. In fact, the excess of sulfate 326 produced in the inoculated experiments (assuming that the reaction occurs via eq. 3) ranged from 0.2 327 to $5.0 \mathrm{mM}$ in agreement with sulfate produced in the blank experiments (between 0.2 and $4.9 \mathrm{mM}$ ). It 328 is important to note that in the experiments in which pyrite was previously washed with $\mathrm{HCl}$, the 329 molar nitrate/sulfate ratio was similar to that of the rest of the experiments, as occurred with the 330 efficiency and rate of nitrate removal (Table 2). This suggests that the presence of possible 331 microparticles and/or impurities on the pyrite surface had no significant effect on the overall process. 
In the non-inoculated flow-through experiments, the measured nitrate/sulfate ratio at the time of maximum nitrate removal was significantly higher than the possible stoichiometric ratios (values

higher than 10, Table 4). In fact, the percentage of nitrate reduction due to pyrite dissolution was calculated to be $1-30 \%$. Moreover, this percentage could be lower since an amount of sulfate was released from dissolution of pyrite by traces of dissolved oxygen, as occurred in the blank flowthrough experiments.

On the one hand, as pyrite powder and solutions were not previously autoclaved, a mixture of both autotrophic and heterotrophic denitrifying bacteria could have enhanced the denitrifying activity not linked to pyrite oxidation. The addition of pyrite as electron donor stimulated the activity of 341 indigenous autotrophic denitrifying microorganisms and could also stimulate the activity of competing microbial populations, such as heterotrophic denitrifiers. Dead and lysed cells of the autotrophic bacteria could act as the carbon source for the heterotrophic bacteria since organic compounds were not provided (Koenig et al., 2005). However, it was difficult to estimate the amount of available $\mathrm{C}$ for heterotrophic denitrification over time and molecular analyses to identify the possible heterotrophic denitrifiers were not performed.

On the other hand, some deficit in sulfate, considering the expected sulfate production, could be partially attributed to passivation of the pyrite surface owing to precipitation of iron (hydr)oxide solid phases. XPS examination showed an enrichment of Fe onto the pyrite surface since surface $\mathrm{Fe} / \mathrm{S}$ ratios increased from 0.50 to up to 0.77 (Table 5), which is consistent with the absence of iron in solution. Solution saturation indexes with respect to solid phases $(\mathrm{SI}=\log (\mathrm{IAP} / \mathrm{Ks})$, where $\mathrm{SI}$ is the saturation index, IAP is the ion activity product and $\mathrm{Ks}_{\mathrm{s}}$ is the solid solubility product), and aqueous speciation of 
354 PHREEQC calculations showed that the output solutions were supersaturated with respect to several 355 iron oxy-hydroxides, such as goethite, ferrihydrite and $\mathrm{Fe}(\mathrm{OH}) 3$. Although aqueous iron was depleted, 356 calculations were run by using a low iron concentration $\left(1 \times 10^{-3} \mathrm{mM}\right)$. Nonetheless, part of this sulfate 357 deficit could be attributed to the precipitation of S-rich secondary phases or elemental S as an 358 intermediate phase.

359 In the inoculated flow-through experiment, the measured nitrate/sulfate ratio was also high (IN-1, 360 Table 4). An iron coating may account for one part of the one part of the deficit in sulfate with respect 361 to the expected sulfate production. XPS confirmed iron enrichment on the surfaces (Table 5) and, 362 according to the PHREEQC calculations, output solutions were supersaturated with respect to iron 363 oxy-hydroxides. However, it has been not possible to account for this discrepancy between the high 364 amount of removed nitrate and the small concentration of released sulfate. One plausible reason could 365 be heterotrophic contamination since aseptic conditions can be difficult to maintain in long-term, 366 continuous-flow experiments inoculated with a pure culture (Claus and Kutzner, 1985).

\subsection{Nitrate reduction rates}

In pyrite-amended batch experiments, nitrate reduction rates were computed assuming zero-order kinetics and using linear regression to fit the remaining nitrate concentrations vs. time (Fig. 1). Computed nitrate reduction rates ranged between 0.09 to $3.50 \mathrm{mmol} \mathrm{NO}^{-} \mathrm{kg}_{\mathrm{py}^{-1}} \mathrm{~d}^{-1}$, with $\sigma_{\text {rate }} \leq 20 \%$ of rate in most cases (Table 2).

372 Nitrate reduction rates were higher in the experiments with $25-50 \mu \mathrm{m}$ pyrite $\left(2.12 \pm 0.83 \mathrm{mmol} \mathrm{NO}_{3}^{-}\right.$ $\left.373 \mathrm{~kg}_{\mathrm{py}^{-1}} \mathrm{~d}^{-1}\right)$ than in the $50-100 \mu \mathrm{m}$ ones $\left(0.39 \pm 0.31 \mathrm{mmol} \mathrm{NO}^{-} \mathrm{kg}_{\mathrm{py}^{-1}} \mathrm{~d}^{-1}\right)$. With initial nitrate concentration 374 of approx. $1 \mathrm{mM}$, the nitrate reduction rate was higher than the rates with approx. 2.5 and $4 \mathrm{mM} \mathrm{NO}_{3}{ }^{-}$ 
$375\left(0.62 \pm 0.34,0.19 \pm 0.01\right.$ and $0.28 \pm 0.23 \mathrm{mmol} \mathrm{NO}^{-} \mathrm{kg}_{\mathrm{py}}{ }^{-1} \mathrm{~d}^{-1}$, respectively). The variability in average rates 376 of the experiments with similar initial conditions (Table 2) could be attributed to different microbial 377 activity (especially in those experiments with low cell density) and/or certain degree of heterogeneity 378 in the range of grain size of the pyrite powders, which has been demonstrated to significantly modify 379 nitrate reduction rates and nitrate removal efficiency.

380 Rate dependence on pyrite grain size implies that the reduction rate depends on exposed pyrite 381 surface area. The larger the surface area, the higher the rate. A large surface area could enhance mass 382 transfer from solid surfaces to solution and/or bacterial attachment to the surface of pyrite grains. 383 Further experiments are necessary to ascertain whether the rate-limiting factor in the overall process is 384 mass transfer or bacterial adhesion.

385 In the flow-through experiments, the pyrite-mass normalized nitrate reduction rate, $\mathrm{R}_{\mathrm{NO}}\left(\mathrm{mol} \mathrm{g}^{-1} \mathrm{~s}^{-}\right.$ $386{ }^{1}$ ) was calculated from the maximum consumption of nitrate according to the expression:

$$
\mathrm{R}_{\mathrm{NO} 3}=\frac{\mathrm{q}\left(\mathrm{C}_{\mathrm{NO} 3}-\mathrm{C}_{\mathrm{NO} 3}^{0}\right)}{m}
$$

where $\mathrm{q}$ is the flow rate $\left(\mathrm{L} \mathrm{s}^{-1}\right)$ of the solution through the reactor, $\mathrm{C}_{\mathrm{NO}}$ and $\mathrm{C}^{0} \mathrm{NO}_{3}$ are the concentrations $\left(\mathrm{mol} \mathrm{L}^{-1}\right)$ of nitrate in the output and input solutions, respectively, and $\mathrm{m}$ is the pyrite mass (g). mmol $\mathrm{NO}_{3}^{-} \mathrm{kg}_{\mathrm{py}^{-1}} \mathrm{~d}^{-1}$ (Table 4). Lower nitrate reduction rate was computed in the experiment performed at $\mathrm{pH} 4.5$ (1.31 $\mathrm{mmol} \mathrm{NO}_{3}{ }^{-} \mathrm{kg}_{\mathrm{py}^{-1}} \mathrm{~d}^{-1}$, Table 4). The nitrate loading rate faintly affected nitrate reduction rates, although, as discussed above, nitrate reduction efficiency was higher in experiments 395 with low nitrate loading rates $\left(0.11-0.25 \mathrm{mmol} \mathrm{NO}_{3}^{-} \mathrm{L}^{-1} \mathrm{~d}^{-1}\right)$. The nitrate reduction rate obtained in the 
396 inoculated experiment was $0.54 \mathrm{mmol} \mathrm{NO}_{3}^{-} \mathrm{kg}_{\mathrm{py}}^{-1} \mathrm{~d}^{-1}$, which was lower than in the non-inoculated 397 experiments although nitrate removal efficiency was higher in the former.

398 Hence, the results indicate that nitrate reduction rates increased by decreasing grain size and initial 399 nitrate concentration. The nitrate reduction rates were lower in the inoculated flow-through 400 experiment than in the non-inoculated ones, although efficiency in nitrate removal was higher in the 401 former.

\section{4. $\mathrm{N}$ and $\mathrm{O}$ isotope fractionation}

403

During denitrification, as nitrate concentration decreases, residual nitrate becomes enriched in 404 heavy isotopes ${ }^{15} \mathrm{~N}$ and ${ }^{18} \mathrm{O}$. When denitrification is treated as a single-step and unidirectional reaction 405 in a closed system, the change in the isotopic composition of nitrate can be modeled using a Rayleigh406 distillation type fractionation model (Mariotti et al., 1981):

$$
\delta^{15} \mathrm{~N}_{\text {residual }}=\delta^{15} \mathrm{~N}_{\text {initial }}+\varepsilon_{\mathrm{N}} \ln \mathrm{f}
$$

$$
\delta^{18} \mathrm{O}_{\text {residual }}=\delta^{18} \mathrm{O}_{\text {initial }}+\varepsilon_{\mathrm{O}} \ln \mathrm{f}
$$

where $\mathrm{f}$ is the unreacted portion of nitrate (residual nitrate concentration divided by the initial nitrate concentration), $\delta$ (residual) and $\delta$ (initial) are the nitrogen or oxygen isotopic compositions (\%o) of the residual and initial nitrate, respectively, and $\varepsilon(\%)$ is the isotopic enrichment factor. Accordingly, $\delta^{15} \mathrm{~N}$ and $\delta^{18} \mathrm{O}$ of dissolved nitrate increase in proportion to the natural logarithm of the residual nitrate fraction.

414 Analysis of $\delta^{15} \mathrm{~N}$ and $\delta^{18} \mathrm{O}$ of dissolved nitrate was carried out in two pyrite-amended batch 415 experiments with 50-100 $\mu \mathrm{m}$ (TD-20) and 25-50 $\mu \mathrm{m}$ (TD-21) size fractions of pyrite (Table 3). The initial 416 values of $\delta^{15} \mathrm{~N}_{\mathrm{NO}}$ and $\delta^{18} \mathrm{O}$ NO3 were $-2.3 \%$ and $+25.1 \%$, respectively, and both values increased over 
417 the experimental runs. In the 50-100 $\mu$ m experiment, after $60 \mathrm{~d}, \delta^{15} \mathrm{~N}_{\mathrm{NO}}$ and $\delta^{18} \mathrm{O}_{\mathrm{NO} O}$ increased to $+8.4 \%$ 418 and $+34.9 \%$, respectively, with $52 \%$ reduction of initial nitrate. In the experiment with $25-50 \mu \mathrm{m}$ 419 pyrite, after $16 \mathrm{~d}, \delta^{15} \mathrm{~N}_{\mathrm{NO}}$ and $\delta^{18} \mathrm{O}_{\mathrm{NO}}$ increased to $+2.6 \%$ and $+29.2 \%$, respectively, with $18 \%$ 420 reduction of initial nitrate. Figure $6 \mathrm{~A}$ depicts $\delta^{15} \mathrm{~N}$ and $\delta^{18} \mathrm{O}$ of the remaining nitrate vs. $\ln \left[\mathrm{NO}_{3^{-}}\right]$in 421 both experiments. In the 50-100 $\mu \mathrm{m}$ pyrite experiment, the values of $\varepsilon \mathrm{N}$ and $\varepsilon \mathrm{O}$ were $-15.0 \%$ and $422-13.5 \%$, respectively, based on the slope of the regression lines. In the experiment with $25-50 \mu \mathrm{m}$ 423 pyrite, the values of $\varepsilon \mathrm{N}$ and $\varepsilon \mathrm{O}$ were $-22.9 \%$ and $-19.0 \%$, respectively. In both experiments, there is a 424 positive correlation $\left(\mathrm{r}^{2}>0.99\right)$ between $\delta^{15} \mathrm{~N}_{\mathrm{NO} 3}$ and $\delta^{18} \mathrm{O}_{\mathrm{NO} 3}$, with slopes of 0.89 and 0.85 , yielding 425 $\varepsilon \mathrm{N} / \varepsilon \mathrm{O}$ ratios of 1.13 and 1.18 , respectively (Fig. $6 \mathrm{~B})$.

To our knowledge, isotope fractionation during autotrophic denitrification in laboratory cultures 427 has not been reported to date. Therefore, the $\varepsilon$ ranges obtained in this study using T. denitrificans 428 culture were compared with those reported in experiments with heterotrophic denitrifying strains 429 under different growth conditions (Table 6). However, it should be noted that the $\mathrm{NO}_{3} / \mathrm{SO}_{4}$ ratio of the 430 TD-20 experiment (2.8) was significantly higher than the stoichiometric ones, suggesting the possible occurrence of heterotrophic contamination (Table 3). In this case, $\varepsilon \mathrm{N}$ and $\varepsilon \mathrm{O}$ could be associated with a mixture of heterotrophic and autotrophic denitrification. These values cannot therefore be unequivocally assigned to the denitrifying activity of $T$. denitrificans. The $\varepsilon \mathrm{N}$ values obtained in this study $(-15.0 \%$ and $-22.9 \%$ ) fall well within the range of values reported in the literature for nitrate 435 reduction to $\mathrm{N}_{2}$ gas by heterotrophic denitrifying cultures (from $-13.4 \%$ o to $-30.0 \%$, Delwiche and Steyn, 1970; Wellman et al., 1968). Nonetheless, the values of $\varepsilon \mathrm{O}(-13.5 \%$ ond $-19.0 \%$ o were lower than 437 those reported by Toyoda et al. (2005) during the production of $\mathrm{N}_{2} \mathrm{O}$ in acetylated experiments with 10 438 or $100 \mathrm{mM} \mathrm{NO}^{-}$by two heterotrophic denitrifying pure cultures (-3\%o to $+32 \%$ ). According to these 
authors, two isotope effects with opposite $\delta^{18} \mathrm{O}$ shifts may arise during nitrate reduction to nitrous oxide: either (1) preferential reduction of the lighter molecules, which yields negative values of $\varepsilon \mathrm{O}$, such as those obtained in the present study, or (2) preferential loss of ${ }^{16} \mathrm{O}$ during the enzymatic 442 reduction of nitrate, which results in an apparent 'inverse isotope effect' with positive values of $\mathrm{O}$ 443 fractionation (Casciotti et al., 2002; Toyoda et al., 2005). The coupled nitrate $\mathrm{N}$ and O isotope 444 fractionation during denitrification has been previously verified in field studies but not in laboratory 445 experiments with pure cultures of denitrifying bacteria. The $\varepsilon \mathrm{N} / \varepsilon \mathrm{O}$ ratio obtained in this study $446(1.15 \pm 0.04)$ is comparable to the ratios obtained from in situ studies of denitrification in groundwater, which range from 0.9 to 2.3 (Otero et al., 2009 and references within). The $\varepsilon \mathrm{N} / \varepsilon \mathrm{O}$ ratio is valuable to trace biogeochemical processes in the $\mathrm{N}$ cycle. It allows to separate processes that overprint one another when they are monitored using $\delta^{15} \mathrm{~N}$ alone, such as denitrification, nitrate assimilation by 450 plants, ammonification, nitrification, $\mathrm{NH}_{3}{ }^{+}$volatilization, mixing processes, etc (Bottcher et al., 1990; Mengis et al., 1999). Moreover, coupling nitrate $\mathrm{N}$ and $\mathrm{O}$ isotopes is used to estimate the intensity of 452 co-existing biogeochemical processes, to identify dominant sources of nitrate in natural waters 453 (Mengis et al., 2001) and to determine the fate of nitrate in areas with diffuse pollution (Otero et al., 454 2009). Further laboratory studies with pure cultures of autotrophic and heterotrophic denitrifying 455 bacteria are required to evaluate the usefulness of the $\varepsilon \mathrm{N} / \varepsilon \mathrm{O}$ ratio in the constraint or discrimination between heterotrophic and autotrophic denitrification. could be expected at field sites dominated by autotrophic denitrification based on pyrite oxidation, such as the Osona aquifer (Otero et al., 2009). However, it should be noted that there is some uncertainty about assigning the isotopic fractionation to denitrification performed exclusively by 
autotrophic denitrifying bacteria. Further laboratory experiments with aquifer material are needed in 462 order to obtain enrichment factors that are characteristic for the specific aquifer.

\section{CONCLUSIONS}

Laboratory experiments were performed to clarify and characterize the role of pyrite in denitrification in order to assess the feasibility of pyrite-driven denitrification of nitrate-contaminated groundwater. Batch experiments were used to evaluate the ability of $T$. denitrificans to reduce nitrate using pyrite and to determine associated $\mathrm{N}$ and $\mathrm{O}$ isotopic fractionation. Flow-through experiments were carried out to explore pyrite-dependent denitrification under similar conditions to the natural environment.

Inoculated experiments demonstrated that T. denitrificans is able to use pyrite as the electron donor

to reduce nitrate. Nitrate reduction rate was dependent on pyrite grain size, nitrate concentration and $\mathrm{pH}$. The results indicated that the extent and rate of denitrification increased as the size of pyrite particles decreased. Moreover, 100\% nitrate removal efficiency was achieved in long-term inoculated 474 flow-through experiments, which proves the long-term pyrite-driven denitrifying capacity of $T$. denitrificans. Furthermore, inoculated batch experiments permitted to calculate $\mathrm{N}$ and $\mathrm{O}$ isotopic enrichment factors for pyrite-driven nitrate reduction by T. denitrificans. To our knowledge, this is the first study determining $\mathrm{N}$ and $\mathrm{O}$ isotope fractionation during denitrification by pure cultures of autotrophic denitrifying bacteria. These values indicated the magnitude of the isotope fractionation that occurs in nitrate-contaminated aquifers dominated by autotrophic denitrification.

Nitrate reduction also occurred under non-sterilized, non-inoculated conditions, but nitrate removal 
482 experiments performed at low nitrate loading rate, almost $100 \%$ of nitrate removal was attained at the 483 end $(375 \mathrm{~d})$. These results suggest that bacteria other than inoculated $T$. denitrificans were able to 484 remove nitrate using pyrite at some stage. Furthermore, it should be noted that, although the bacterial 485 community present in the non-inoculated experiments was not native to a nitrate contaminated 486 aquifer, it was able to adapt to the new conditions and as a result reduce nitrate, probably by a 487 combination of both autotrophic and heterotrophic denitrification.

488 Hence, the addition of pyrite to enhance activity of denitrifying bacteria could be considered for 489 future water management strategies to remove nitrate at the concentrations commonly found in 490 contaminated agricultural groundwater (up to $5 \mathrm{mM}$, e.g. Otero et al., 2009). However, a drawback of 491 using the pyrite-driven denitrification process as a remediation strategy is at some extent the release 492 of trace metals (e.g. As, Ni) and sulfate as a result of pyrite oxidation. Hence, care should be taken of 493 the source and chemical characterization of the pyrite used as amendment. Furthermore, increasing 494 the sulfate content in groundwater could contribute to eutrophication of surface waters (Smolders et 495 al., 2006; Haaijer et al., 2007) and sulfate discharge into freshwater might require post-treatment 496 processing. Future experiments using sediments from nitrate-contaminated aquifers should address 497 denitrification enhancement by addition of pyrite to stimulate indigenous denitrifying bacteria.

\section{Acknowledgments}

499 This work was funded by projects CICYT-CGL2008-06373-C03-01 and TRACE PET 2008-0034 of the 500 Spanish Government and the project 2009 SGR 103 from the Catalan Government. We thank the 501 Serveis Científics Tècnics of the Universitat de Barcelona and the Woods Hole Oceanographic 502 Institution for their services. We also thank Vanessa Ouro from the Institute of Environmental 
503 Assessment and Water Research (CSIC) and Josep Elvira from the Institute of Earth Sciences "Jaume 504 Almera" (CSIC) for analytical assistance. We thank to George Von Knorring for improving the English 505 style of this paper. We are grateful to two anonymous reviewers and Associate Editor, Dr. Jeremy Fein 506 for their constructive comments and suggestions that significantly improved the original manuscript.

\section{REFERENCES}

508 Aravena, R., Robertson, W.D., 1998. Use of multiple isotope tracers to evaluate denitrification in 509

510 ground water: Study of nitrate from a large-flux septic system plume. Ground Water 36(6), 975-981.

511 Barford, C.C., Montoya, J.P., Altabet, M.A., Mitchell, R., 1999. Steady-state nitrogen isotope effects of 512 $\mathrm{N}_{2}$ and $\mathrm{N}_{2} \mathrm{O}$ production in Paracoccus denitrificans. Appl. Environ. Microbiol. 65(3), 989-994.

513 Beller, H.R., 2005. Anaerobic, nitrate-dependent oxidation of U(IV) oxide minerals by the 514 chemolithoautotrophic bacterium Thiobacillus denitrificans. Appl. Environ. Microbiol. 71(4), 515 2170-2174.

516 Beller, H.R., Chain, P.S.G., Letain, T.E., Chakicherla, A., Larimer, F.W., Richardson, P.M., Coleman, 517 M.A., Wood, A.P., Kelly, D.P., 2006. The genome sequence of the obligately chemolithoautotrophic, facultatively anaerobic bacterium Thiobacillus denitrificans. J. Bacteriol. 188(4), 1473-1488.

523 Benz, M., Brune, A., Schink, B., 1998. Anaerobic and aerobic oxidation of ferrous iron at neutral pH by chemoheterotrophic nitrate-reducing bacteria. Arch. Microbiol. 169(2), 159-165.

Betlach, M.R., Tiedje, J.M., 1981. Kinetic explanation for accumulation of nitrite, nitric oxide, and 526 nitrous oxide during bacterial denitrification. Appl. Environ. Microbiol. 42(6), 1074-1084. 
527 Blaszczyk, M., 1993. Effect of medium composition on the denitrification of nitrate by Paracoccus 528 denitrificans. Appl. Environ. Microbiol. 59(11), 3951-3953.

529 Böttcher, J., Strebel, O., Voerkelius, S., Schmidt, H.L., 1990. Using isotope fractionation of nitrate 530 nitrogen and nitrate oxygen for evaluation of microbial denitrification in a sandy aquifer. J. $531 \quad$ Hydrol. 114(3-4), 413-424.

532 Brunauer, S., Emmett, P.H., Teller, E., 1938. Adsorption of gases in multimolecular layers. J. Am. 533 Chem. Soc. 60(2), 309-319.

534 Bryan, B.A., Shearer, G., Skeeters, J.L., Kohl, D.H., 1983. Variable expression of the nitrogen isotope 535 effect associated with denitrification of nitrite. J. Biol. Chem. 258(14), 8613-8617.

Casciotti, K.L., Sigman, D.M., Hastings, M.G., Bohlke, J.K., Hilkert, A., 2002. Measurement of the oxygen isotopic composition of nitrate in seawater and freshwater using the denitrifier method. Anal. Chem. 74(19), 4905-4912.

Cey, E.E., Rudolph, D.L., Aravena, R., Parkin, G., 1999. Role of the riparian zone in controlling the distribution and fate of agricultural nitrogen near a small stream in southern Ontario. J. Contam. Hydrol. 37(1-2), 45-67.

Claus, G., Kutzner, H.J., 1985. Physiology and kinetics of autotrophic denitrification by Thiobacillus denitrificans. Appl. Microbiol. Biotechnol. 22(4), 283-288.

Cravotta, C.A., 1998. Effect of sewage sludge on formation of acidic ground water at a reclaimed coal mine. Ground Water 36(1), 9-19.

546 Choe, S.H., Ljestrand, H.M., Khim, J., 2004. Nitrate reduction by zero-valent iron under different $\mathrm{pH}$ regimes. Appl. Geochem. 19(3), 335-342.

548 Delwiche, C.C., Steyn, P.L., 1970. Nitrogen isotope fractionation in soils and microbial reactions. 549 Environ. Sci. Technol. 4(11), 929-935.

550 Devlin, J.F., Eedy, R., Butler, B.J., 2000. The effects of electron donor and granular iron on nitrate 551 transformation rates in sediments from a municipal water supply aquifer. J. Contam. Hydrol.

553 Fukada, T., Hiscock, K.M., Dennis, P.F., Grischek, T., 2003. A dual isotope approach to identify 554 denitrification in groundwater at a river-bank infiltration site. Water Res. 37(13), 3070-3078. 
Haaijer, S.C.M., Lamers, L.P.M., Smolders, A.J.P., Jetten, M.S.M., Op de Camp, H.J.M., 2007. Iron 556 sulfide and pyrite as potential electron donors for microbial nitrate reduction in freshwater 557 wetlands. Geomicrobiol. J. 24(5), 391-401.

Hansen, H.C.B., Guldberg, S., Erbs, M., Koch, C.B., 2001. Kinetics of nitrate reduction by green rusts 559 effects of interlayer anion and Fe(II): Fe(III) ratio. Appl. Clay Sci. 18(1-2), 81-91.

Jorgensen, C.J., Jacobsen, O.S., Elberling, B., Aamand, J., 2009. Microbial oxidation of pyrite coupled to 561 nitrate reduction in anoxic groundwater sediment. Environ. Sci. Technol. 43(13), 4851-4857.

562 Knowles, R., 1982. Denitrification. Microbiol. Rev. 46(1), 43-70.

563 Koenig, A., Zhang, T., Liu, L., Fang, H., 2005. Microbial community and biochemistry process in 564 autosulfurotrophic denitrifying biofilm. Chemosphere 58(8), 1041-1047.

Korom, S.F., 1992. Natural denitrification in the saturated zone - A review. Water Resour. Res. 28(6), 566 $1657-1668$.

Lasaga, A.C., 1998. Kinetic Theory in the Earth Sciences. Princeton University Press, Princeton, New 568 Jersey, $728 \mathrm{pp}$.

Le Bideau, L., Dudoignon, P., 1996. Evidence of natural denitrification mechanism at Beuxes (Vienne, France). C.R. Acad. Sci., Ser. IIa: Sci. Terre Planets 322, 555-562.

Mariotti, A., Germon, J.C., Hubert, P., Kaiser, P., Létolle, R., Tardieux, A., Tardieux, P., 1981. Experimental determination of nitrogen kinetic isotope fractionation - Some principles Illustration for the denitrification and nitrification processes. Plant Soil 62(3), 413-430.

Mengis, M., Walther, U., Bernasconi, S.M., Wehrli, B., 2001. Limitations of using $\delta^{18} \mathrm{O}$ for the source 575 identification of nitrate in agricultural soils. Environ. Sci. Technol. 35(9), 1840-1844.

Otero, N., Torrentó, C., Soler, A., Menció, A., Mas-Pla, J., 2009. Monitoring groundwater nitrate 580 attenuation in a regional system coupling hydrogeology with multi-isotopic methods: The case of Plana de Vic (Osona, Spain). Agric., Ecosyst. Environ. 133(1-2), 103-113. 
582 Parkhurst, D.L., 1995. User's guide to PHREEQC--A computer program for speciation, reaction-path, 583 advective-transport, and inverse geochemical calculations. U.S. Geological Survey WaterResources Investigations Report 95-4227, 143 pp.

Pauwels, H., Ayraud-Vergnaud, V., Aquilina, L., Molénat, J., 2010. The fate of nitrogen and sulfur in hard-rock aquifers as shown by sulfate-isotope tracing. Appl. Geochem. 25(1), 105-115.

Pauwels, H., Foucher, J.C., Kloppmann, W., 2000. Denitrification and mixing in a schist aquifer: influence on water chemistry and isotopes. Chem. Geol. 168(3-4), 307-324.

Pauwels, H., Kloppmann, W., Foucher, J.C., Martelat, A., Fritsche, V., 1998. Field tracer test for denitrification in a pyrite-bearing schist aquifer. Appl. Geochem. 13(6), 767-778.

Postma, D., 1990. Kinetics of nitrate reduction by detrital Fe(II)-silicates. Geochim. Cosmochim. Acta 54(3), 903-908.

Postma, D., Boesen, C., Kristiansen, H., Larsen, F., 1991. Nitrate reduction in an unconfined sandy aquifer - Water chemistry, reduction processes and geochemical modeling. Water Resour. Res. 27(8), 2027-2045.

Schippers, A., Jorgensen, B.B., 2002. Biogeochemistry of pyrite and iron sulfide oxidation in marine sediments. Geochim. Cosmochim. Acta 66(1), 85-92.

Schwientek, M., Einsiedl, F., Stichler, W., Stögbauer, A., Strauss, H., Maloszewski, P., 2008. Evidence for denitrification regulated by pyrite oxidation in a heterogeneous porous groundwater system. Chem. Geol. 255(1-2), 60-67.

Shearer, G., Kohl, D.H., 1988. Nitrogen isotopic fractionation and ${ }^{18} \mathrm{O}$ exchange in relation to the mechanism of denitrification of nitrite by Pseudomonas stutzeri. J. Biol. Chem. 263(26), 1323113245.

Sierra-Alvarez, R., Beristain-Cardoso, R., Salazar, M., Gómez, J., Razo-Flores, E., Field, J.A., 2007. Chemolithotrophic denitrification with elemental sulfur for groundwater treatment. Water Res. 41(6), 1253-1262.

Sigman, D.M., Casciotti, K.L., Andreani, M., Barford, C., Galanter, M., Bohlke, J.K., 2001. A bacterial method for the nitrogen isotopic analysis of nitrate in seawater and freshwater. Anal. Chem. 73(17), 4145-4153. 
610 Smolders, A.J.P., Lamers, L.P.M., Lucassen, E.C.H.E.T., Van Der Velde, G., Roelofs, J.G.M., 2006. Internal eutrophication: How it works and what to do about it - A review. Chem. Ecol. 22(2), 93-111.

615 Straub, K.L., Benz, M., Schink, B., Widdel, F., 1996. Anaerobic, nitrate-dependent microbial oxidation 616 of ferrous iron. Appl. Environ. Microbiol. 62(4), 1458-1460.

617 Sutka, R.L., Ostrom, N.E., Ostrom, P.H., Breznak, J.A., Gandhi, H., Pitt, A.J., Li, F., 2006. 618 Distinguishing nitrous oxide production from nitrification and denitrification on the basis of 619 isotopomer abundances. Appl. Environ. Microbiol. 72(1), 638-644.

620 Thomsen, J.K., Geest, T., Cox, R.P., 1994. Mass spectrometric studies of the effect of pH on the 621 accumulation of intermediates in denitrification by Paracoccus denitrificans. Appl. Environ. 622 Microbiol. 60(2), 536-541.

623 Toyoda, S., Mutobe, H., Yamagishi, H., Yoshida, N., Tanji, Y., 2005. Fractionation of $\mathrm{N}_{2} \mathrm{O}$ isotopomers 624 during production by denitrifier. Soil Biol. Biochem. 37(8), 1535-1545.

625 Van Rijn, J., Tal, Y., Barak, Y., 1996. Influence of volatile fatty acids on nitrite accumulation by a 626 Pseudomonas stutzeri strain isolated from a denitrifying fluidized bed reactor. Appl. Environ. 627 Microbiol. 62(7), 2615-2620.

628 Wagner, C.D., 1983. Sensitivity factors for XPS analysis of surface atoms. J. Electron. Spectrosc. Relat. 629 Phenom. 32(2), 99-102.

630 Weber, K.A., Picardal, F.W., Roden, E.E., 2001. Microbially catalyzed nitrate-dependent oxidation of 631 biogenic solid-phase Fe(II) compounds. Environ. Sci. Technol. 35(8), 1644-1650.

632 Wellman, R.P., Cook, F.D., Krouse, H.R., 1968. Nitrogen-15: Microbiological alteration of abundance. $633 \quad$ Science 161(3838), 269-270.

634 Widdel, F., Bak, F., 1992. Gram-negative mesophilic sulfate-reducing bacteria, in: A. Balows, H.G.T., 635 M. Dworkin, W. Harper and K.-H. Schleifer (Ed.), The Prokaryotes. Springer Verlag, New 636 York, pp. 3352-3378. 
637 Zhang, Y.-C., Slomp, C.P., Broers, H.P., Passier, H.F., Cappellen, P.V., 2009. Denitrification coupled to 638 pyrite oxidation and changes in groundwater quality in a shallow sandy aquifer. Geochim. 639 Cosmochim. Acta 73(22), 6716-6726.

640 Zumft, W.G., 1997. Cell biology and molecular basis of denitrification. Microbiol. Mol. Biol. Rev. 61(4), $641 \quad 533-616$.

642 
644 Figure 1. Variation of nitrate concentration over time in representative pyrite-amended batch 645 experiments inoculated with T. denitrificans. (A) Consumption of nitrate over time in the experiments 646 performed with approx. $2.5 \mathrm{mM} \mathrm{NO}_{3}$ solution; (B) Consumption of nitrate over time in the 647 experiments amended with 50-100 $\mu \mathrm{m}$ pyrite and inoculated with approx. $10^{8}$ cells $\mathrm{mL}^{-1}$; $(\mathrm{C}) \mathrm{NO}_{3^{-}}$and $648 \mathrm{NO}_{2}^{-}$concentration vs. time of experiments TD-1c and TD-2c; Solid lines represent the fitting of 649 measured $\mathrm{NO}_{3}{ }^{-}$concentration versus time used to compute zero-order nitrate reduction rates. 650 Determination coefficients $\left(\mathrm{R}^{2}\right)$ were $\geq 0.9$ except in 2 experiments.

651 Figure 2. Variation of $\mathrm{NO}_{3}{ }^{-}$and $\mathrm{NO}_{2}{ }^{-}$concentration vs. time in input (i) and output (o) solutions of two 652 representative flow-through experiments. See Table 4. (A) Experiment inoculated with T. denitrificans 653 culture (IN-1); (B) One non-inoculated experiment (NON-3a). The ellipse shows the nitrate 654 concentration values used to calculate nitrate reduction rate (see eq. 7).

655 Figure 3. Variation of nitrate and nitrite concentration over time in input (i) and output (o) solutions of 656 four representative non-inoculated flow-through experiments. See Table 4. (A) Experiment NON-2. 657 Nitrate reduction apparently ceased after 230 d, but 10 d later, it restarted and about 94\% nitrate 658 removal efficiency was achieved at the end (370 d). (B) Experiment NON-4a. In contrast to other non659 inoculated experiments, a lag of approx. $80 \mathrm{~d}$ was observed before nitrate reduction started. (C) 660 Experiment NON-4c. Nitrate reduction started at $50 \mathrm{~d}$ and did not cease during the duration of the 661 run $(350 \mathrm{~d})$. (D) NON-6b, performed with high nitrate loading rate $\left(0.34 \mathrm{mmol} \mathrm{NO}^{-} \mathrm{L}^{-1} \mathrm{~d}^{-1}\right)$. In contrast 662 to the experiments with lower nitrate loading rate, nitrate removal was less effective and lasted only $66330 \mathrm{~d}$. 
664 Figure 4. Variation of nitrate and nitrite concentration over time in input (i) and output (o) solutions of 665 one of the non-inoculated flow through-experiments (NON-3b). (A) Evolution of nitrate and nitrite 666 concentrations. (B) Evolution of the sum of nitrate and nitrite concentrations in the output solutions. 667 Nitrate reduction commenced at the start of the experiment and lasted $120 \mathrm{~d}$. In the first $70 \mathrm{~d}$, nitrate 668 was reduced to nitrite, which in turn, reduced to a N-gaseous compound. Thereafter, between 70 and $669120 \mathrm{~d}$, nitrate reduced to nitrite, and nitrite was not reduced. After $120 \mathrm{~d}$, nitrate reduction ceased.

670 Figure 5. Variation of $S$ concentration over time in batch and flow-through experiments. (A) $S$ 671 concentration vs. time in representative blank and inoculated pyrite-amended experiments. Solid lines 672 represent the fitting of measured and $S$ concentration versus time used to compute zero-order $S$ 673 production rates, $\mathrm{r}_{\mathrm{s} .}$ (B) $\mathrm{S}$ concentration vs. time in one representative flow-through experiment.

674 Figure 6. Isotopic results of the two pyrite-amended batch experiments inoculated with $T$. denitrificans 675 and focusing on calculate isotope fractionation: TD-21 (with 25-50 $\mu \mathrm{m}$ pyrite) and TD-20 (50-100 $\mu \mathrm{m}$ 676 pyrite). (A) $\delta^{15} \mathrm{~N}$ (filled symbols) and $\delta^{18} \mathrm{O}_{\mathrm{NO}}$ (open symbols) vs. $\ln \left[\mathrm{NO}_{3}\right]$. Values of $\varepsilon \mathrm{N}$ and $\varepsilon \mathrm{O}$ were 677 obtained from the slope of the regression lines; (B) $\delta^{18} \mathrm{O}$ vs. $\delta^{15} \mathrm{~N}_{\mathrm{NO}}$. Determination coefficients $\left(\mathrm{R}^{2}\right)$ 678 ranged from 0.889 to 0.993 in both figures. 
Figure 1
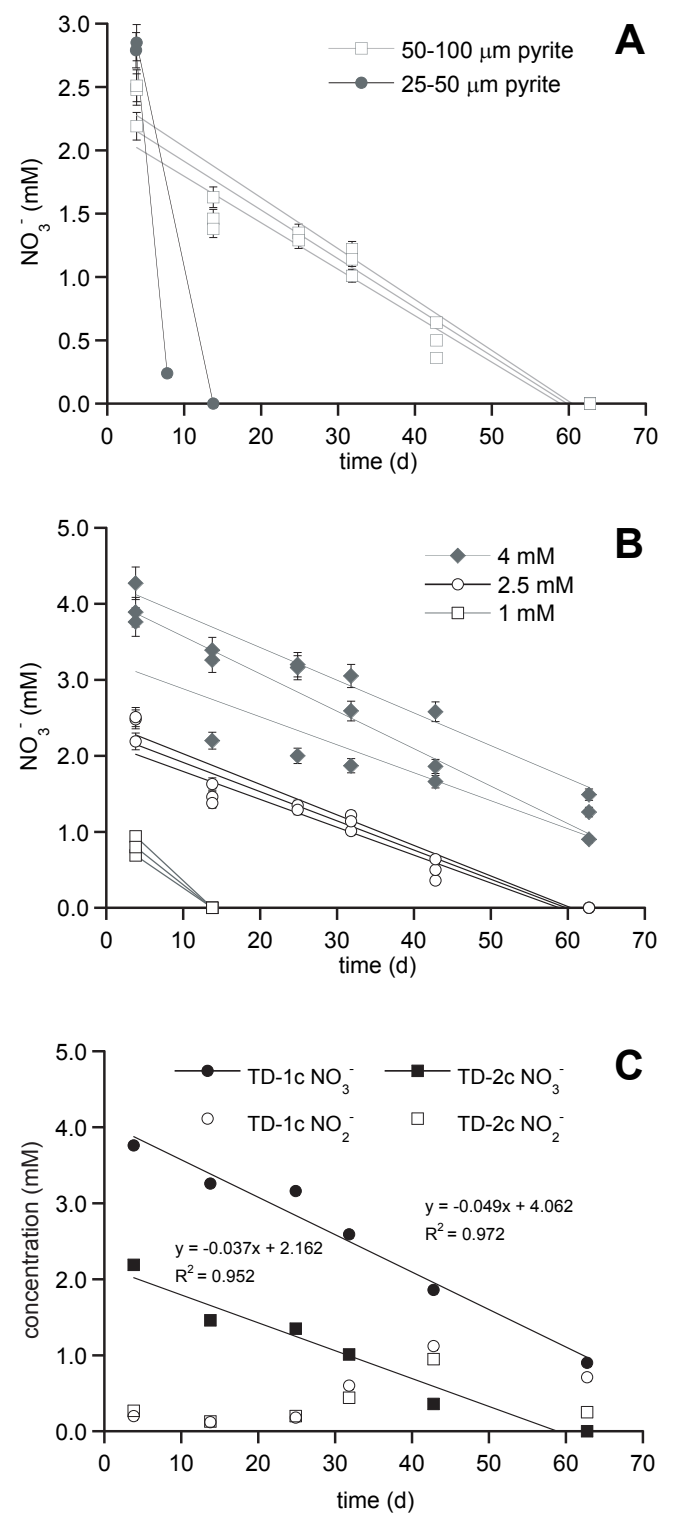


\section{Figure 2}
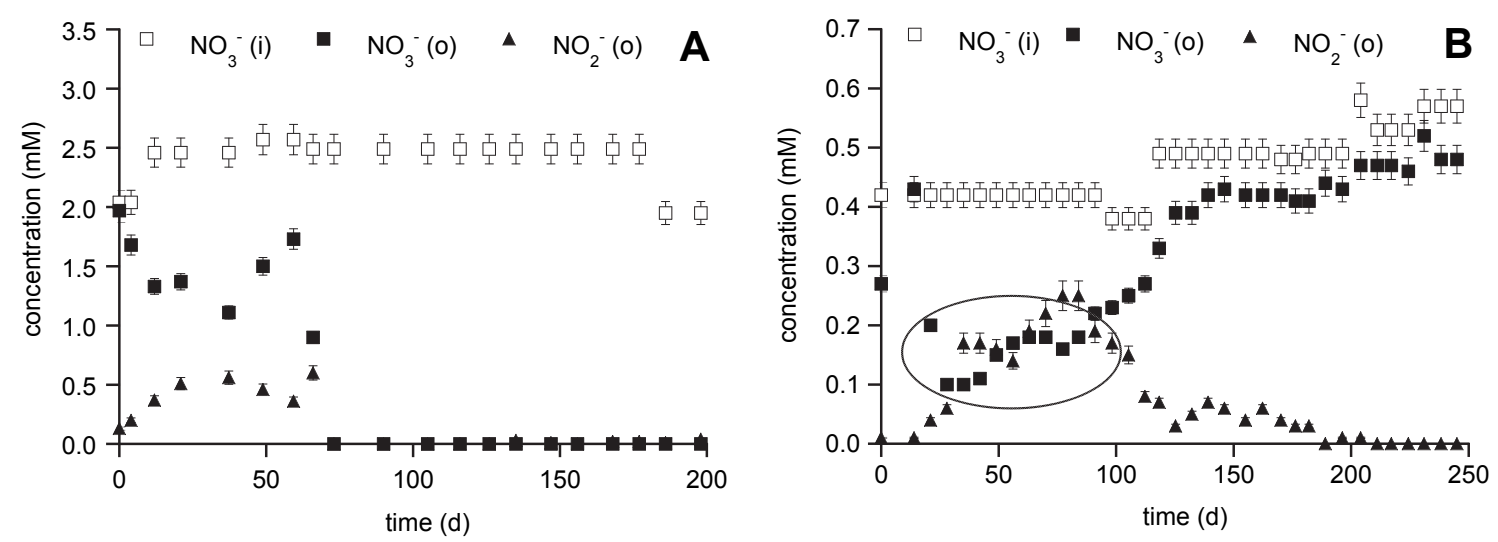
Figure 3
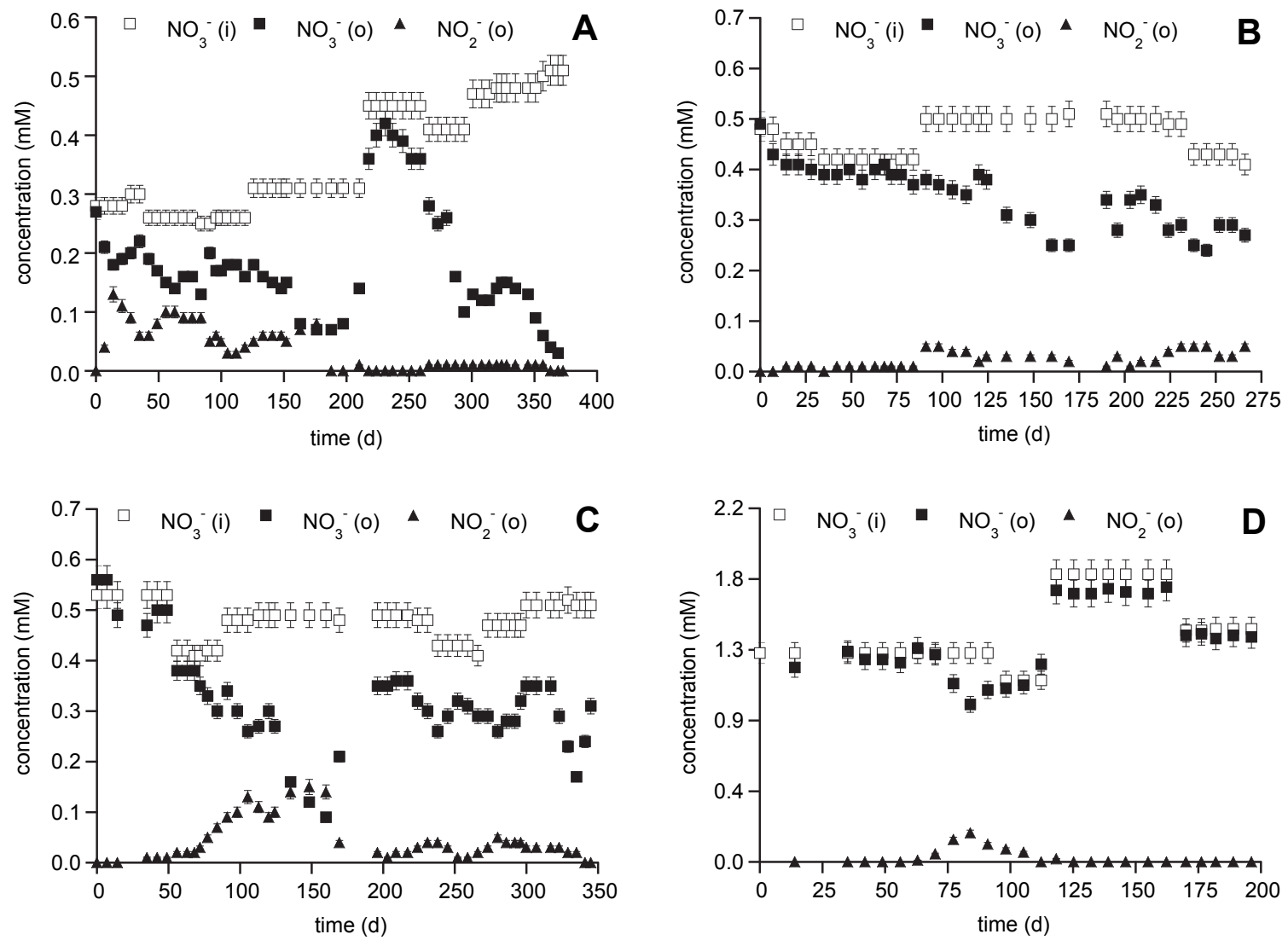
Figure 4
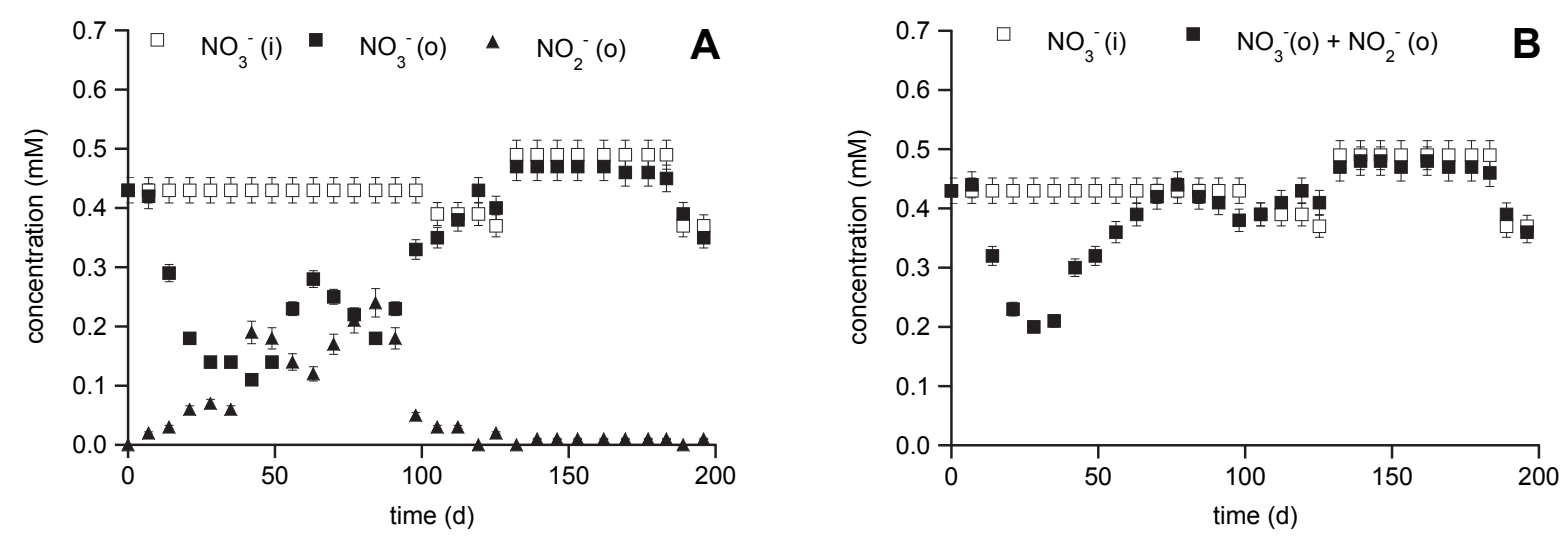


\section{Figure 5}
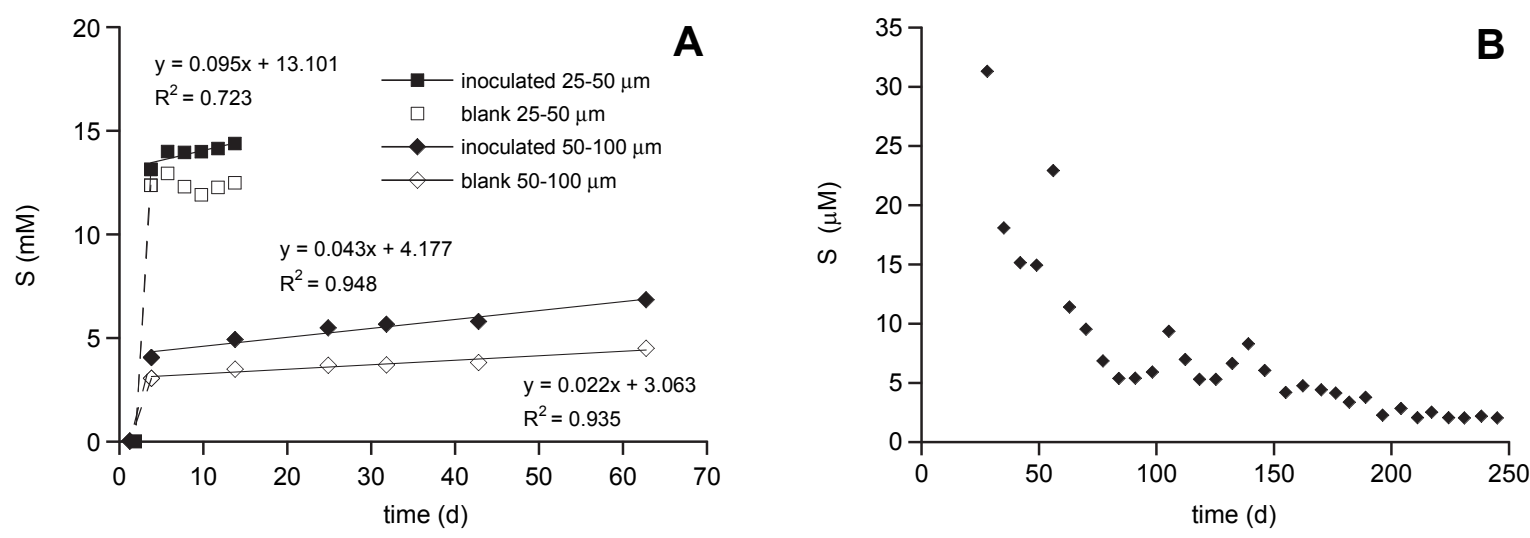


\section{Figure 6}
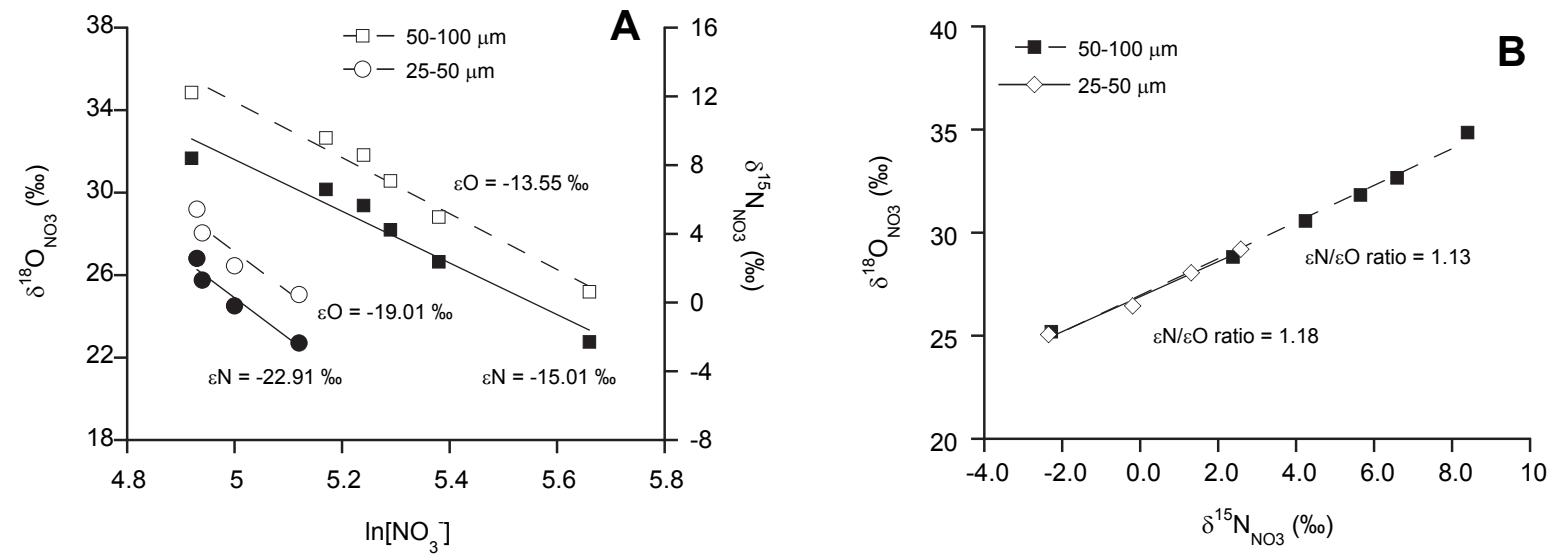
Table 1. Experimental conditions and results of the control batch experiments

\begin{tabular}{|c|c|c|c|c|c|c|}
\hline \multirow[t]{2}{*}{ exp. } & inoculum & $\begin{array}{l}\text { grain } \\
\text { size }\end{array}$ & $\begin{array}{l}\text { initial } \\
\text { nitrate }\end{array}$ & $\begin{array}{l}\text { final } \\
\text { nitrate } \\
(1)\end{array}$ & $\begin{array}{l}\text { final } \\
\text { BET }\end{array}$ & $\begin{array}{l}\text { sulfate } \\
\text { produced } \\
\text { (2) }\end{array}$ \\
\hline & cells $\mathrm{mL}^{-1}$ & $\mu \mathbf{m}$ & $\mathbf{m M}$ & $\mathbf{m M}$ & $m^{2} g^{-1}$ & $\mathbf{m M}$ \\
\hline \multicolumn{7}{|c|}{ Pyrite-free experiments } \\
\hline TD-control-10 & $\sim 10^{7}$ & - & 4.46 & 4.50 & - & - \\
\hline TD-control-9 & $\sim 10^{7}$ & - & 4.37 & 4.31 & - & - \\
\hline TD-control-15 & $\sim 10^{7}$ & - & 4.31 & 4.29 & - & - \\
\hline TD-control-11 & $\sim 10^{5}$ & - & 4.58 & 4.57 & - & - \\
\hline TD-control-12 & $\sim 10^{5}$ & - & 4.57 & 4.31 & - & - \\
\hline TD-control-16 & $\sim 10^{7}$ & - & 3.76 & 3.34 & - & - \\
\hline TD-control-17 & - & - & 5.14 & 4.98 & - & - \\
\hline TD-control-13 & - & - & 4.75 & 4.84 & - & - \\
\hline TD-control-14 & - & - & 4.75 & 4.83 & - & - \\
\hline TD-control-18 & - & - & 4.40 & 4.19 & - & - \\
\hline TD-control-7 & - & - & 4.24 & 4.21 & - & - \\
\hline TD-control-8 & - & - & 3.78 & 4.09 & - & - \\
\hline \multicolumn{7}{|c|}{ Blank experiments with pyrite } \\
\hline TD-blank-17 & - & $50-100$ & 5.08 & 5.15 & 0.61 & 0.25 \\
\hline TD-blank-23 & - & $50-100$ & 4.97 & 5.02 & 0.27 & 0.69 \\
\hline TD-blank-16 & - & $50-100$ & 4.92 & 5.16 & 0.40 & 3.17 \\
\hline TD-blank-24 & - & $50-100$ & 4.54 & 4.54 & 0.22 & 0.53 \\
\hline TD-blank-8 & - & $50-100$ & 4.31 & 4.36 & 0.79 & 1.45 \\
\hline TD-blank-10 & - & $50-100$ & 2.90 & 2.69 & 0.53 & 1.38 \\
\hline TD-blank-11 & - & $50-100$ & 2.71 & 2.74 & 0.91 & 1.95 \\
\hline TD-blank-12 & - & $50-100$ & 2.71 & 2.79 & 0.52 & 2.00 \\
\hline TD-blank-9 & - & $50-100$ & 2.58 & 2.75 & 0.55 & 1.25 \\
\hline TD-blank-13 & - & $50-100$ & 1.08 & 0.94 & 0.64 & 3.26 \\
\hline TD-blank-22 ${ }^{(3)}$ & - & $25-50$ & 5.15 & 5.12 & 1.89 & 0.43 \\
\hline TD-blank-21 ${ }^{(3)}$ & - & $25-50$ & 5.06 & 5.08 & 0.78 & 0.25 \\
\hline TD-blank-19 & - & $25-50$ & 5.04 & 5.05 & 1.05 & 0.56 \\
\hline TD-blank-18 & - & $25-50$ & 3.52 & 3.62 & 1.09 & 0.82 \\
\hline TD-blank-15 & - & $25-50$ & 1.52 & 1.43 & 1.46 & 4.93 \\
\hline TD-blank-14 & - & $25-50$ & 0.99 & 1.08 & 1.85 & 0.70 \\
\hline
\end{tabular}

(1) After $60 \mathrm{~d}$ in pyrite-free experiments and in blank experiments with $50-100 \mu \mathrm{m}$ pyrite and after $14 \mathrm{~d}$ in blank experiments with $25-50 \mu \mathrm{m}$ pyrite

(2) From time 0 to $60 \mathrm{~d}(50-100 \mu \mathrm{m}$ pyrite) or from 0 to $14 \mathrm{~d}(25-50 \mu \mathrm{m}$ pyrite)

(3) Pyrite samples were previously washed with $6 \mathrm{M} \mathrm{HCl}$ 
Table 2. Experimental conditions and results of the pyrite-amended batch experiments inoculated with $T$. denitrificans

\begin{tabular}{|c|c|c|c|c|c|c|c|c|c|}
\hline \multirow{2}{*}{ variable } & \multirow{2}{*}{ exp. } & \multirow{2}{*}{$\begin{array}{l}\begin{array}{l}\text { initial } \\
\text { nitrate }\end{array} \\
\mathrm{mM}\end{array}$} & \multirow[t]{2}{*}{$\begin{array}{l}\text { final } \\
\text { nitrate }^{(1)}\end{array}$} & \multirow[t]{2}{*}{ final BET } & \multirow{2}{*}{$\begin{array}{l}\begin{array}{l}\text { overall } \\
\mathrm{NO}_{3}^{-} \\
\text {removal } \\
\text { (1) }\end{array} \\
\%\end{array}$} & \multicolumn{2}{|c|}{$\mathrm{NO}_{3}^{-}$reduction rate } & \multirow{2}{*}{$\begin{array}{l}\text { sulfate } \\
\text { produced }^{(3)}\end{array}$} & \multirow{2}{*}{$\begin{array}{l}\mathrm{NO}_{3} / \mathrm{SO}_{4} \\
\text { ratio }\end{array}$} \\
\hline & & & & & & $\underset{\mathrm{kg}^{-1} \mathrm{~d}^{-1}}{\mathrm{mmol}_{3}}$ & $\underset{(2)}{\sigma}$ rate & & \\
\hline \multicolumn{10}{|l|}{$50-100 \mu \mathrm{m}$} \\
\hline \multicolumn{10}{|l|}{$\sim 10^{8}$ cells $\mathrm{mL}^{-1}$} \\
\hline \multirow{4}{*}{$\sim 4 \mathrm{mM} \mathrm{NO}_{3}^{-}$} & TD-1a & 3.89 & 1.26 & 0.65 & 68 & 0.18 & 0.06 & 6.75 & 0.4 \\
\hline & $\mathrm{TD}-1 \mathrm{~b}$ & 3.89 & 1.49 & 0.67 & 62 & 0.22 & 0.02 & 1.97 & 1.2 \\
\hline & TD-1c & 3.76 & 0.90 & 0.81 & 76 & 0.25 & 0.02 & 1.73 & 1.7 \\
\hline & mean \pm SD & $3.85 \pm 0.08$ & $1.22 \pm 0.30$ & $0.71 \pm 0.09$ & $69 \pm 7$ & $0.22 \pm 0.03$ & & $3.48 \pm 2.83$ & $1.1 \pm 0.7$ \\
\hline \multirow[t]{4}{*}{$\sim 2.5 \mathrm{mM} \mathrm{NO}_{3}^{-}$} & TD-2a & 2.51 & 0.00 & 0.47 & 100 & 0.20 & 0.02 & 2.79 & 0.9 \\
\hline & TD-2b & 2.48 & 0.00 & 0.79 & 100 & 0.19 & 0.03 & 2.94 & 0.8 \\
\hline & TD-2c & 2.18 & 0.00 & 0.66 & 100 & 0.18 & 0.02 & 2.43 & 0.9 \\
\hline & mean \pm SD & $2.39 \pm 0.18$ & 0.00 & $0.64 \pm 0.17$ & 100 & $0.19 \pm 0.01$ & & $2.72 \pm 0.26$ & $0.9 \pm 0.0$ \\
\hline \multirow[t]{5}{*}{$\sim 1 \mathrm{mM} \mathrm{NO}_{3}^{-}$} & TD-3a & 0.94 & 0.00 & 0.64 & 100 & $0.47^{(5)}$ & - & 0.81 & 1.2 \\
\hline & TD-3b & 0.80 & 0.00 & 0.72 & 100 & $0.40^{(5)}$ & - & 1.88 & 0.4 \\
\hline & TD-3c & 0.90 & 0.00 & 0.56 & 100 & $0.45^{(5)}$ & - & 2.18 & 0.4 \\
\hline & TD-3d & 0.69 & 0.00 & 0.74 & 100 & $0.35^{(5)}$ & - & 2.05 & 0.3 \\
\hline & mean \pm SD & $0.83 \pm 0.11$ & 0.00 & $0.67 \pm 0.09$ & 100 & $0.42 \pm 0.06$ & & $1.73 \pm 0.62$ & $0.6 \pm 0.4$ \\
\hline \multicolumn{10}{|l|}{$\sim 10^{7}$ cells $\mathrm{mL}^{-1}$} \\
\hline \multirow[t]{2}{*}{$\sim 4 \mathrm{mM} \mathrm{NO}_{3}^{-}$} & TD-4 & 4.38 & $1.17^{(6)}$ & 1.15 & $73^{(6)}$ & 0.76 & 0.15 & 1.89 & 1.7 \\
\hline & TD-5 & 3.82 & 2.50 & 0.53 & 35 & 0.12 & 0.02 & 2.84 & 0.5 \\
\hline \multirow[t]{2}{*}{$\sim 1 \mathrm{mM} \mathrm{NO}_{3}^{-}$} & TD-6 & 1.06 & 0.00 & 1.12 & 100 & $1.23^{(5)}$ & - & 1.19 & 0.9 \\
\hline & TD-7 & 0.66 & 0.00 & 1.04 & 100 & $0.81^{(5)}$ & - & 0.41 & 1.6 \\
\hline \multicolumn{10}{|l|}{$\sim 10^{5}$ cells $\mathrm{mL}^{-1}$} \\
\hline \multirow[t]{2}{*}{$\sim 4 \mathrm{mM} \mathrm{NO}_{3}^{-}$} & TD-8 & 4.44 & $3.64^{(6)}$ & 0.45 & $19^{(6)}$ & 0.09 & 0.02 & 0.95 & 0.8 \\
\hline & TD-9 & 3.71 & 2.09 & 0.45 & 44 & 0.38 & 0.11 & 4.24 & 0.4 \\
\hline \multicolumn{10}{|l|}{$25-50 \mu \mathrm{m}$} \\
\hline \multicolumn{10}{|l|}{$\sim 10^{8}$ cells $\mathrm{mL}^{-1}$} \\
\hline$\sim 4 \mathrm{mM} \mathrm{NO}_{3}^{-}$ & TD-10 & 4.76 & 0.00 & 1.27 & 100 & $2.28^{(5)}$ & - & 3.98 & 1.2 \\
\hline \multicolumn{10}{|l|}{$\sim 10^{7}$ cells $\mathrm{mL}^{-1}$} \\
\hline \multirow[t]{4}{*}{$\sim 4 \mathrm{mM} \mathrm{NO}_{3}^{-}$} & TD-12 & 4.29 & 2.15 & 0.56 & 50 & 1.06 & 0.08 & 1.24 & 1.7 \\
\hline & TD-13 ${ }^{(7)}$ & 3.94 & 0.88 & 1.02 & 78 & 1.40 & 0.13 & 1.52 & 2.0 \\
\hline & TD-14 ${ }^{(7)}$ & 3.72 & 0.00 & 0.90 & 100 & 2.50 & 0.22 & 3.68 & 1.0 \\
\hline & TD-15 & 3.32 & 0.00 & 0.34 & 100 & 3.50 & 0.69 & 3.06 & 1.2 \\
\hline \multicolumn{10}{|l|}{$\sim 10^{5}$ cells $\mathrm{mL}^{-1}$} \\
\hline$\sim 4 \mathrm{mM} \mathrm{NO}_{3}^{-}$ & TD-17 & 3.79 & 0.55 & 0.33 & 86 & 1.71 & 0.28 & 2.56 & 1.3 \\
\hline & TD-18 & 3.52 & 0.00 & 1.59 & 100 & 2.09 & 0.55 & 2.67 & 1.3 \\
\hline
\end{tabular}

(1) After $60 \mathrm{~d}$ in experiments with 50-100 $\mu \mathrm{m}$ pyrite and after $14 \mathrm{~d}$ in experiments with $25-50 \mu \mathrm{m}$ pyrite

(2) Standard deviation of the linear regression of nitrate concentration over time (Fig. 1)

(3) From 0 to $60 \mathrm{~d}(50-100 \mu \mathrm{m}$ pyrite) or from 0 to $14 \mathrm{~d}(25-50 \mu \mathrm{m}$ pyrite)

(4) Ratio between measured nitrate reduced and sulfate produced

(5) Apparent nitrate reduction rates. Complete nitrate removal was detected at first sampling

(6) After $25 \mathrm{~d}$ in experiment TD-4 and after $42 \mathrm{~d}$ in experiment TD-8

(7) Pyrite samples were previously washed with $6 \mathrm{M} \mathrm{HCl}$ 
Table 3. Experimental conditions and results of the two pyrite-amended batch experiments inoculated with approximately $10^{7}$ cells $\mathrm{mL}^{-1} T$. denitrificans culture focusing on calculate isotope fractionation

\begin{tabular}{|c|c|c|c|c|c|c|c|c|c|}
\hline \multirow[t]{2}{*}{ exp. } & \multirow{2}{*}{$\begin{array}{l}\text { grain } \\
\text { size } \\
\mu \mathrm{m}\end{array}$} & \multirow{2}{*}{$\begin{array}{l}\begin{array}{l}\text { initial } \\
\text { nitrate }\end{array} \\
\mathrm{mM}\end{array}$} & \multirow{2}{*}{$\begin{array}{l}\begin{array}{l}\text { final } \\
\text { nitrate } \\
\text { (1) }\end{array} \\
\text { mM }\end{array}$} & \multirow{2}{*}{$\begin{array}{l}\text { final } \\
\text { BET } \\
\mathrm{m}^{2} \mathrm{~g}^{-1}\end{array}$} & \multirow{2}{*}{$\begin{array}{l}\begin{array}{l}\text { overall } \\
\mathrm{NO}_{3}^{-} \\
\text {removal }^{(1)}\end{array} \\
\%\end{array}$} & \multicolumn{2}{|c|}{$\mathrm{NO}_{3}^{-}$reduction rate } & \multirow[t]{2}{*}{$\begin{array}{l}\text { sulfate } \\
\text { produced }\end{array}$} & \multirow{2}{*}{$\begin{array}{l}\mathrm{NO}_{3} / \mathrm{SO}_{4} \\
\text { ratio }\end{array}$} \\
\hline & & & & & & $\begin{array}{l}\mathrm{mmol} \mathrm{NO}_{3}^{-} \\
\mathrm{kg}^{-1} \mathrm{~d}^{-1}\end{array}$ & $\sigma$ rate $^{(2)}$ & & \\
\hline TD-20 & $50-100$ & 4.61 & 2.20 & 0.31 & 52 & 0.19 & 0.03 & 0.87 & 2.8 \\
\hline TD-21 & $25-50$ & 2.71 & 2.22 & 0.48 & 18 & 0.19 & 0.04 & 1.84 & 0.3 \\
\hline
\end{tabular}

(1) After $60 \mathrm{~d}$ in experiment TD-20 and after $14 \mathrm{~d}$ in experiment TD-21

(2) Standard deviation of the linear regression of nitrate concentration over time (Fig. 1)

(3) From 0 to $60 \mathrm{~d}$ (TD-20) or from 0 to $14 \mathrm{~d}$ (TD-21)

(4) Ratio between measured nitrate reduced and sulfate produced 
Table 4. Experimental conditions and results of blank, inoculated and non-inoculated flow-through experiments

\begin{tabular}{|c|c|c|c|c|c|c|c|c|c|c|c|c|c|c|}
\hline \multirow{2}{*}{$\exp }$. & \multirow[t]{2}{*}{$\begin{array}{l}\text { nitrate } \\
\text { input }^{(1)}\end{array}$} & \multirow[t]{2}{*}{ HRT } & \multirow{2}{*}{$\begin{array}{l}\begin{array}{l}\text { nitrate } \\
\text { loading } \\
\text { rate }\end{array} \\
\text { mmol } \\
\mathrm{NO}_{3}^{-} \mathrm{L}^{-1} \\
\mathrm{~d}^{-1}\end{array}$} & \multirow{2}{*}{$\begin{array}{l}\text { output } \\
\text { pH }\end{array}$} & \multirow{2}{*}{$\begin{array}{l}\text { final } \\
\text { BET } \\
\mathrm{m}^{2} \mathrm{~g}^{-1}\end{array}$} & \multirow{2}{*}{$\begin{array}{l}\text { pyrite } \\
\text { mass }\end{array}$} & \multirow{2}{*}{$\begin{array}{l}\begin{array}{l}\text { max. } \\
\text { nitrate } \\
\text { reduced }\end{array} \\
\mathrm{mM}\end{array}$} & \multirow{2}{*}{$\begin{array}{l}\begin{array}{l}\text { max. } \\
\text { nitrate } \\
\text { removal }\end{array} \\
\%\end{array}$} & \multirow{2}{*}{$\begin{array}{l}\begin{array}{l}\text { nitrate } \\
\text { reduction } \\
\text { rate }\end{array} \\
\mathrm{mmol} \mathrm{NO}_{3}^{-} \\
\mathrm{kg}^{-1} \mathbf{d}^{-1}\end{array}$} & \multirow{2}{*}{$\begin{array}{l}\begin{array}{l}\text { S } \\
\text { (s.s.) }\end{array} \\
\mu \mathrm{mol} \mathrm{L}^{-1}\end{array}$} & \multirow{2}{*}{$\begin{array}{l}\text { Fe } \\
\text { (s.s.) }\end{array}$} & \multirow{2}{*}{$\begin{array}{l}\mathrm{NO}_{3} / \\
\mathrm{SO}_{4} \\
\text { ratio } \\
\text { (2) (3) }\end{array}$} & \multirow{2}{*}{$\begin{array}{l}\% \mathrm{NO}_{3}^{-} \\
\text {reduced due } \\
\text { to pyrite } \\
\text { oxidation } \\
\text { (4) }\end{array}$} & \multirow{2}{*}{ comments } \\
\hline & & & & & & & & & & & & & & \\
\hline \multicolumn{15}{|c|}{ Sterilized blank experiment } \\
\hline BLANK-1 & 0.43 & 3.1 & 0.14 & 7.2 & 0.50 & 0.79 & - & - & - & 1.58 & b.d.1. & - & - & \\
\hline \multicolumn{15}{|c|}{ Inoculated experiment } \\
\hline $\mathrm{IN}-1$ & 2.46 & 11.6 & 0.21 & 7.0 & 0.77 & 10.00 & 2.46 & 100 & 0.54 & 2.18 & b.d.l. & 24 & $6-10$ & Complete nitrate removal at $70 \mathrm{~d}$. Lasted until the end $(200 \mathrm{~d})$ \\
\hline \multicolumn{15}{|c|}{ Non-inoculated experiments } \\
\hline NON-1 & 0.42 & 3.2 & 0.13 & 4.5 & 0.44 & 1.00 & 0.10 & 23 & 1.31 & 2.35 & 1.50 & 18 & $8-14$ & $\begin{array}{l}\text { Maximum nitrate removal at } 50 \mathrm{~d} \text {. Nitrate reduction stopped at } \\
75 \mathrm{~d}\end{array}$ \\
\hline NON-2 & 0.31 & 2.7 & 0.11 & 7.0 & 0.40 & 0.99 & 0.24 & 78 & 4.03 & 2.67 & b.d.l. & 40 & $5-7$ & $\begin{array}{l}\text { Maximum nitrate removal at } 175 \mathrm{~d} \text {. Nitrate reduction stopped } \\
\text { at } 230 \mathrm{~d} \text {. Nitrate removal restarted at } 240 \mathrm{~d} \text { and } 94 \% \text { of } \\
\text { reduction at the end }(370 \mathrm{~d})\end{array}$ \\
\hline NON-3a & 0.42 & 3.1 & 0.13 & 7.0 & 0.48 & 1.00 & 0.32 & 77 & 3.88 & 2.25 & b.d.l. & 18 & $12-17$ & $\begin{array}{l}\text { Maximum nitrate removal at } 35 \mathrm{~d} \text {. Nitrate reduction stopped at } \\
230 \mathrm{~d}\end{array}$ \\
\hline NON-3b & 0.43 & 3.9 & 0.11 & 7.0 & 0.53 & 1.00 & 0.32 & 75 & 3.30 & 4.62 & b.d.l. & 23 & $10-14$ & $\begin{array}{l}\text { Maximum nitrate removal at } 40 \mathrm{~d} \text {. Nitrate reduction stopped at } \\
120 \mathrm{~d}\end{array}$ \\
\hline NON-3c & 0.42 & 3.5 & 0.12 & 7.5 & 0.49 & 1.00 & 0.29 & 69 & 3.00 & 1.29 & b.d.l. & 17 & $14-18$ & $\begin{array}{l}\text { Maximum nitrate removal at } 40 \mathrm{~d} \text {. Nitrate reduction stopped at } \\
140 \mathrm{~d} \text {. Nitrate removal restarted at } 160 \mathrm{~d} \text { and } 60 \% \text { of reduction } \\
\text { at the end }(250 \mathrm{~d})\end{array}$ \\
\hline NON-3d & 0.43 & 3.9 & 0.11 & 7.5 & 0.51 & 1.00 & 0.21 & 49 & 2.38 & 2.34 & b.d.l. & 10 & $18-28$ & $\begin{array}{l}\text { Maximum nitrate removal at } 20 \mathrm{~d} \text {. Nitrate reduction stopped at } \\
75 \mathrm{~d} \text {. Nitrate removal restarted at } 120 \mathrm{~d} \text { and } 60 \% \text { of reduction } \\
\text { at the end }(240 \mathrm{~d})\end{array}$ \\
\hline NON-3e & 0.40 & 2.3 & 0.17 & 6.7 & 0.53 & 0.80 & 0.18 & 42 & 3.34 & 3.87 & b.d.l. & 59 & $4-5$ & $\begin{array}{l}\text { Initial stage of } 50 \mathrm{~d} \text { with } 1.1 \mathrm{mM} \mathrm{NO}_{3}{ }^{-} \text {input. Maximum } \\
\text { nitrate removal at } 85 \mathrm{~d} \text {. Nitrate reduction stopped at } 110 \mathrm{~d}\end{array}$ \\
\hline NON-3f & 0.44 & 2.5 & 0.18 & 7.5 & 0.34 & 1.00 & 0.28 & 57 & 5.68 & 1.32 & b.d.l. & $>150$ & $1-2$ & $\begin{array}{l}\text { Initial stage of } 65 \mathrm{~d} \text { with } \mathrm{pH} 3 \mathrm{HCl} \text { input. Maximum nitrate } \\
\text { removal at } 195 \mathrm{~d} \text {. Nitrate reduction did not cease and } 60 \% \text { of } \\
\text { reduction at the end }(365 \mathrm{~d})\end{array}$ \\
\hline NON-4a & 0.46 & 3.4 & 0.14 & 7.3 & 0.50 & 0.99 & 0.26 & 51 & 2.57 & 2.00 & b.d.l. & $>150$ & $1-2$ & $\begin{array}{l}\text { Lag of } 85 \mathrm{~d} \text { before nitrate reduction started. Maximum nitrate } \\
\text { removal at } 130 \mathrm{~d} \text {. Nitrate reduction did not cease }\end{array}$ \\
\hline NON-4b & 0.48 & 2.7 & 0.18 & 7.0 & 0.31 & 0.99 & 0.26 & 55 & 3.68 & 1.33 & b.d.l. & $>150$ & 1 & $\begin{array}{l}\text { Initial stage of } 200 \mathrm{~d} \text { with } 1.0 \mathrm{mM} \mathrm{NO}_{3} \text { input. Maximum } \\
\text { nitrate removal at } 330 \mathrm{~d} \text {. Nitrate reduction did not cease and } \\
98 \% \text { of reduction at the end }(380 \mathrm{~d})\end{array}$ \\
\hline NON-4c & 0.49 & 2.9 & 0.17 & 7.4 & 0.29 & 1.00 & 0.40 & 81 & 4.85 & 1.56 & b.d.l. & $>150$ & $1-2$ & $\begin{array}{l}\text { Maximum nitrate removal at } 160 \mathrm{~d} \text { Nitrate reduction did not } \\
\text { cease }\end{array}$ \\
\hline NON-4d & 0.50 & 3.2 & 0.16 & 7.7 & 0.32 & 1.00 & 0.12 & 28 & 1.62 & 2.15 & b.d.l. & $>150$ & $1-2$ & $\begin{array}{l}\text { Initial stage of } 65 \mathrm{~d} \text { with } 1.0 \mathrm{mM} \mathrm{NO}_{3}^{-} \text {input. Maximum } \\
\text { nitrate removal at } 165 \mathrm{~d} \text {. Nitrate reduction did not cease and } \\
83 \% \text { of reduction at the end }(240 \mathrm{~d})\end{array}$ \\
\hline NON-4e & 0.53 & 2.7 & 0.20 & 7.4 & 4.58 & 0.79 & 0.32 & 66 & 5.42 & 4.62 & b.d.l. & $>150$ & $1-3$ & $\begin{array}{l}\text { Maximum nitrate removal at } 130 \mathrm{~d} \text {. Nitrate reduction did not } \\
\text { cease and } 98 \% \text { of reduction at the end }(335 \mathrm{~d})\end{array}$ \\
\hline NON-5a & 0.86 & 3.5 & 0.25 & 7.2 & 0.64 & 1.01 & 0.48 & 49 & 3.81 & 1.84 & b.d.l. & 79 & $2-4$ & $\begin{array}{l}\text { Lag of } 90 \mathrm{~d} \text { before nitrate reduction started. Maximum nitrate } \\
\text { removal at } 195 \mathrm{~d} \text {. Nitrate reduction did not cease }\end{array}$ \\
\hline NON-5b & 0.88 & 3.5 & 0.25 & 7.3 & 0.41 & 1.01 & 0.43 & 41 & 3.78 & 3.45 & b.d.l. & 77 & $2-4$ & $\begin{array}{l}\text { Lag of } 100 \mathrm{~d} \text { before nitrate reduction started. Maximum nitrate } \\
\text { removal at } 195 \mathrm{~d} \text {. Nitrate reduction did not cease }\end{array}$ \\
\hline
\end{tabular}




\begin{tabular}{|c|c|c|c|c|c|c|c|c|c|c|c|c|c|c|}
\hline NON-6a & 1.29 & 3.9 & 0.33 & 7.5 & 0.62 & 1.00 & 0.38 & 29 & 2.57 & 2.20 & b.d.l. & 86 & $3-4$ & $\begin{array}{l}\text { Maximum nitrate removal at } 90 \mathrm{~d} \text {. Nitrate reduction stopped at } \\
160 \mathrm{~d}\end{array}$ \\
\hline NON-6b & 1.30 & 3.9 & 0.34 & 7.2 & 0.60 & 1.00 & 0.32 & 24 & 3.89 & 3.11 & b.d.1. & 43 & $5-7$ & $\begin{array}{l}\text { Maximum nitrate removal at } 85 \mathrm{~d} \text {. Nitrate reduction stopped at } \\
105 \mathrm{~d}\end{array}$ \\
\hline NON-7 & 1.72 & 3.5 & 0.50 & 7.0 & 0.34 & 1.00 & 0.31 & 18 & 4.45 & 3.36 & b.d.l. & 57 & $3-5$ & $\begin{array}{l}\text { Maximum nitrate removal at } 90 \mathrm{~d} \text {. Nitrate reduction stopped at } \\
120 \mathrm{~d}\end{array}$ \\
\hline
\end{tabular}

b.d.l. = below detection limit $\left(3.12 \mu \mathrm{mol} \mathrm{L}{ }^{-1} \mathrm{~S} ; 0.36 \mu \mathrm{mol} \mathrm{L}^{-1} \mathrm{Fe}\right)$

HRT $=$ hydraulic retention time

s.s. $=$ steady state

(1) Nitrate average concentration of the input solution over the whole experiment

(2) Ratio between measured nitrate reduced and sulfate produced

(3) At time of maximum nitrate removal

(4) Based on the amount of nitrate reduced, sulfate and nitrite produced and the stoichiometry of the eqs. (3-6) 
Table 5. Results obtained from X-ray Photoelectron Spectroscopy (XPS) determinations on the initial and reacted pyrite samples of some flow-through experiments. Surface stoichiometry is represented by molar ratios. Atomic concentrations of $\mathrm{Fe}$ and $\mathrm{S}$ in the pyrite surfaces were estimated by normalizing out the remaining elements (oxygen and adventitious carbon)

\begin{tabular}{llll}
\hline \multirow{2}{*}{ sample } & $\mathbf{F e}$ & $\mathbf{S}$ & $\mathbf{F e} / \mathbf{S}$ \\
\cline { 2 - 3 } & $\mathbf{a t .} \%$ & & \\
\hline Initial & 33.5 & 66.5 & 0.50 \\
NON-6b & 39.1 & 60.9 & 0.64 \\
NON-3b & 43.6 & 56.4 & 0.77 \\
IN-1 & 58.8 & 41.2 & 1.42 \\
\hline
\end{tabular}


Table 6. Comparison between the enrichment factors for ${ }^{15} \mathrm{~N}$ and ${ }^{18} \mathrm{O}$ estimated in laboratory experiments with pure heterotrophic denitrifying cultures reported in the literature with those estimated in the present study using T. denitrificans

\begin{tabular}{|c|c|c|c|c|c|c|}
\hline species & system & $\varepsilon N(\%)$ & $\varepsilon O(\%)$ & $\varepsilon \mathbf{N} / \varepsilon \mathbf{O}$ & reference & comments \\
\hline \multicolumn{7}{|c|}{ Heterotrophic denitrifying bacteria } \\
\hline Paracoccus denitrificans & $\mathrm{NO}_{3}{ }^{-} \rightarrow \mathrm{N}_{2} \mathrm{O}$ & $-28.6 \pm 1.9$ & n.d. & n.d. & \multirow{2}{*}{$\begin{array}{l}\text { Barford et al. } \\
\text { (1999) }\end{array}$} & \multirow{2}{*}{$\begin{array}{l}\text { steady-state reactor, acetate as } \\
\text { electron donor, } 30 \mathrm{mM} \mathrm{NO}_{3}^{-}\end{array}$} \\
\hline Paracoccus denitrificans & $\mathrm{N}_{2} \mathrm{O} \rightarrow \mathrm{N}_{2}$ & $-12.9 \pm 5.8$ & n.d. & n.d. & & \\
\hline Pseudomonas denitrificans & $\mathrm{NO}_{3}^{-} \rightarrow \mathrm{N}_{2}$ & -13.4 to -20.8 & n.d. & n.d. & $\begin{array}{l}\text { Delwiche and Steyn } \\
\text { (1970) }\end{array}$ & $\begin{array}{l}\text { batch, glucose as electron } \\
\text { donor }\end{array}$ \\
\hline Pseudomonas stutzeri & $\mathrm{NO}_{3}^{-} \rightarrow \mathrm{N}_{2}$ & -20 to -30 & n.d. & n.d. & $\begin{array}{l}\text { Wellman et al. } \\
(1968)\end{array}$ & batch, 0.01 to $0.03 \mathrm{mM} \mathrm{NO}_{3}^{-}$ \\
\hline Pseudomonas chlororaphis & $\mathrm{NO}_{3}^{-} \rightarrow \mathrm{N}_{2} \mathrm{O}$ & -12.7 & n.d. & n.d. & \multirow{2}{*}{ Sutka et al. (2006) } & \multirow{2}{*}{$\begin{array}{l}\text { batch, citrate as electron donor, } \\
10 \mathrm{mM} \mathrm{NO}_{3}^{-}\end{array}$} \\
\hline Pseudomonas aerofaciens & $\mathrm{NO}_{3}^{-} \rightarrow \mathrm{N}_{2} \mathrm{O}$ & -36.7 & n.d. & n.d. & & \\
\hline Pseudomonas fluorescens & $\mathrm{NO}_{3}^{-} \rightarrow \mathrm{N}_{2} \mathrm{O}$ & -39 to $-31^{(1)}$ & +13 to $+32^{(1)}$ & n.d. & \multirow{3}{*}{$\begin{array}{l}\text { Toyoda et al. } \\
(2005)\end{array}$} & \multirow{3}{*}{$\begin{array}{l}\text { batch, citrate as electron donor, } \\
\text { acetylated, } 10 \text { to } 100 \mathrm{mM} \mathrm{NO}_{3}^{-}\end{array}$} \\
\hline & $\mathrm{NO}_{3}^{-} \rightarrow \mathrm{N}_{2} \mathrm{O}$ & -22 to $-17^{(1)}$ & -3 to $-1^{(1)}$ & n.d. & & \\
\hline Paracoccus denitrificans & $\mathrm{NO}_{3}^{-} \rightarrow \mathrm{N}_{2} \mathrm{O}$ & -22 to $-10^{(1)}$ & +4 to $+23^{(1)}$ & n.d. & & \\
\hline Pseudomonas stutzeri & $\mathrm{NO}_{2}^{-} \rightarrow \mathrm{N}_{2} ?$ & -5 to -20 & n.d. & n.d. & Bryan et al. (1983) & $\begin{array}{l}\text { batch, succinate as electron } \\
\text { donor, } 0.07 \text { to } 2.2 \mathrm{mM} \mathrm{NO}_{2}^{-}\end{array}$ \\
\hline Pseudomonas stutzeri & $\mathrm{NO}_{2}^{-} \rightarrow \mathrm{N}_{2} \mathrm{O}$ & -9.9 to -19.6 & n.d. & n.d. & $\begin{array}{l}\text { Shearer and Kohl } \\
\text { (1988) }\end{array}$ & $\begin{array}{l}\text { batch, succinate as electron } \\
\text { donor, } 0.1 \text { to } 2.3 \mathrm{mM} \mathrm{NO}_{2}^{-}\end{array}$ \\
\hline \multicolumn{7}{|c|}{ Autotrophic denitrifying bacteria } \\
\hline Thiobacillus denitrificans & $\mathrm{NO}_{3}^{-} \rightarrow \mathrm{N}_{2} ?$ & $-22.9^{(2)}$ & $-19.0^{(2)}$ & 1.18 & this study (TD-21) & $\begin{array}{l}\text { batch, } 25-50 \mu \mathrm{m} \text { pyrite as } \\
\text { electron donor, } 2.7 \mathrm{mM} \mathrm{NO}_{3}^{-}\end{array}$ \\
\hline Thiobacillus denitrificans & $\mathrm{NO}_{3}^{-} \rightarrow \mathrm{N}_{2} ?$ & $-15.0^{(2)}$ & $-13.5^{(2)}$ & 1.13 & this study (TD-20) & $\begin{array}{l}\text { batch, } 50-100 \mu \mathrm{m} \text { pyrite as } \\
\text { electron donor, } 4.6 \mathrm{mM} \mathrm{NO}_{3}^{-}\end{array}$ \\
\hline
\end{tabular}

(1) $\varepsilon \mathrm{N}$ (or $\varepsilon \mathrm{O}$ ) calculated as difference between $\delta^{15} \mathrm{~N}_{\mathrm{N} 2 \mathrm{O}}\left(\right.$ or $\left.\delta^{18} \mathrm{O}_{\mathrm{N} 2 \mathrm{O}}\right)$ and $\delta^{15} \mathrm{~N}_{\mathrm{NO} 3}\left(\right.$ or $\left.\delta^{18} \mathrm{O}_{\mathrm{NO} 3}\right)$

(2) see text for details 